Irina Poczyńskaja

Uralski Uniwersytet Federalny, Jekaterynburg, Rosja

poirvi12@gmail.com

ORCID 0000-0002-7431-856X

http://doi.org/10.33077/zbkh.2018.12.poczynskaja

\title{
Polskie książki z XVIII - pocz. XX w. w Jekaterynburgu
}

\author{
Abstract \\ Polish books from the $18^{\text {th }}$ to the beginning of the $20^{\text {th }}$ \\ centuries in Ekaterinburg
}

This article analyses Polish book collections in Ekaterinburg. The author has found such collections in four of the city's libraries: the Sverdlovsk regional library, the Sverdlovsk regional history museum, the Central Academic Library of the Ural branch of the Russian Academy of Sciences, and the Ural Law University. In the article, the history of how these collections were formed and their particularities are discussed, as are the fates of individual books. The largest collection ( 250 books at the Sverdlovsk regional library) has as its basis books from the libraries of the Catholic Church of St Anna and the Catholic Philanthropic Society. The foundation of the Polish collection at the Sverdlovsk regional history museum consists of books from the archive of the Ural Society for the Admirers of the Natural Sciences. This collection includes a total of 17 works: the earliest of them coming from the beginning of the $18^{\text {th }}$ century. A further focused search for Polish books in the libraries of Ekaterinburg would probably result in new findings.

Key words: Russia - Ekaterinburg - Polish books - libraries - book collections - history.

Slowa kluczowe: Rosja - Jekaterynburg - polonika - biblioteki - księgozbiory - historia.

Na Uralu, w tym również w Jekaterynburgu, od momentu założenia miasta w 1723 r. mieszkało sporo Polaków. Wśród polskich osadników byli zesłańcy, których liczba wzrosła szczególnie w XIX w., kiedy to wysyłano na Ural i dalej na Syberię uczestników polskich powstań: listopadowego i styczniowego, jak również działaczy polskiego ruchu socjalistycznego i robotniczego. 
Należy zaznaczyć, że niektórzy Polacy dobrowolnie wstępowali do rosyjskiej służby państwowej ${ }^{1}$. Jednym z kierowników budowy twierdzy, na terenie której funkcjonowały zakłady metalurgiczne oraz fabryki, a która w przyszłości stała się miastem Jekaterynburgiem, był Polak - Jan Kralewicz. Był on uczestnikiem III wojny północnej (1700-1721), walcząc po stronie Szwecji; dostawszy się do niewoli złożył przysięgę carowi Piotrowi I i wstąpił do wojska rosyjskiego, służył najpierw w Sankt-Petersburskim Pułku, a potem został przeniesiony do miasta gubernialnego Tobolska w zachodniej Syberii. Na budowę jekaterynburskiej twierdzy kapitan Kralewicz przybył jako dowódca batalionu piechoty Tobolskiego Pułku w 1723 r. Oprócz dowódcy w składzie batalionu byli inni Polacy. Kralewicz brał również udział w budowie innych fabryk na Uralu-Pyskorskiej i Siniaczychinskiej, łapał „,bandytów” na uralskich rzekach Czusowaja, Sylwa, Kama, w latach 1736-1737 uczestniczył w walkach przeciwko powstańcom baszkirskim i zmarł w czasie tej kampanii²

Później w uralskich zakładach i fabrykach na stanowiskach urzędniczych różnego szczebla, od sekretarzy zaczynając a na zarządcach przedsiębiorstw górniczych i leśnych kończąc, pracowało wielu Polaków. Jako przykład można przytoczyć sylwetki Aleksieja Gizielewskiego i jego syna Iwana, którzy żyli w drugiej połowie XVIII - na początku XIX w. Aleksiej awansował na stanowisko sędziego powiatowego, a potem został członkiem Drugiego Departamentu Jekaterynburskiego Zarządu Górniczego, Iwan zaś był urzędnikiem górniczym czternastego stopnia (Schichtmeister). Jako inżynier w uralskich zakładach pracował Konstantyn Golachowski, potomek Polaków, którzy osiedlili się na Uralu w XVIII w. Dosłużył się stanowiska Dyrektora Górniczego zakładów Gorobłagodatskich i przyczynił się do ich modernizacji. Znane są również nazwiska wielu innych Polaków, którzy pracowali w XIX w. jako lekarze, są to Onufry Niechwedowicz, Feliks Sokołowski, Ignacy Worwiński, Michał Zubryński i in. ${ }^{3}$

1 Поляки в Пермском крае: очерки истории и этнографии, под ред. А.В. Черныха, Санкт-Петербург 2009; А.А. Сафронов, Поляки на Урале в коние ХIX в. (по материалам первой всеобщей переписи населения Российской империи 1897 г.), [in:] Документ. Архив. Иистория. Современность. Материаль IV Международной научно-практической конференции, посвященной 20-летию подготовки документоведов в Уральском федеральном университете, Екатеринбург, 1-4 ноября 2012 г., Екатеринбург 2012, s. 256-260, [online] http://elar.urfu.ru/hadle/10995/35508 [dostęp 3.01.2018]; Т.П. Мосунова, А.В. Черноухов, Екатеринбург и его окрестности в жизни поляков в XVIII - начале XX в., [in:] Архивы России и Польши: история, проблемы и перспективы развития. Сборник научных трудов, под общ. ред. Л. Мазур и Я. Лосовски, Екатеринбург 2012, s. 13-22; Э.А. Черноухов, Врачи - поляки на горных заводах Урала в ХIX в., „Вопросы Истории” 2014, № 4, s. 148-152; С.М. Рязанов, Поляки на полицейской службе в Пермской губернии (конеи XIX - начало XX в.), „Вестник Пермского Университета" 2015, № 4, s. 110-119.

2 Т.П. Мосунова, А.В. Черноухов, Екатеринбург..., s. 14.

3 М.С. Бессонов, История северного Урала в лицах (1589-1917). Биографический 
W XIX w. polsko-katolickie towarzystwo dobroczynne w Jekaterynburgu było aktywnie wspierane przez Alfonsa Poklewskiego-Koziełła, przemysłowca, asesora do spraw handlu produktami monopolowymi, przedsiębiorcę górniczego, właściciela kopalni złota. Poklewski-Koziełł był jednym z założycieli przemysłu azbestowego na Uralu, zainicjował pierwszą regularną żeglugę po rzekach Zachodniej Syberii poprzez kupno i uruchomienie pierwszego parowca. Posiadał przedsiębiorstwa w wielu miejscowościach Uralu i Syberii, w tym w Jekaterynburgu. Pochodząc z powiatu lepelskiego w guberni witebskiej, Poklewski-Koziełł karierę urzędnika państwowego rozpoczął w Petersburgu, jednak w 1838 r. przeniósł się na Syberię. W ślad za nim na Ural i Zachodnią Syberię przyjechali jego krewni ${ }^{4}$. Będąc katolikiem, A. Poklewski-Koziełł finansowo wspierał katolicką społeczność Jekaterynburga, w której liczebnie przeważali Polacy, m.in. dał pieniądze na budowę kościoła w Jekaterynburgu. Parafia katolicka w tym mieście została założona w 1876 r., natomiast do tego czasu miejscowymi katolikami opiekowali się przyjeżdżający z Kazania lub Permu księża. W 1882 r. rozpoczęto budowę kościoła pw. Świętej Anny. Dwa lata później odbyła się jego uroczysta konsekracja. Jekaterynburska parafia obejmowała terytorium kilku powiatów Uralu i Zachodniej Syberii (jekaterynburski, wierchoturski, kamyszłowski, szadryński, irbicki). Według spisu ludności Imperium Rosyjskiego z 1897 r. w Jekaterynburgu było 323 katolików, w całej parafii zaś ok. 1000 osób. W tym samym roku wspólnota katolicka otrzymała w postaci darowizny od syna A. Poklewskiego dworek w centrum miasta, w którym ulokowała się szkoła oraz parafialny księgozbiór, zebrany i ciągle uzupełniany przez wiernych, jak również siedziba założonego w 1907 r. rzymsko-katolickiego towarzystwa dobroczynności, które, jak wskazują oznakowania na książkach, posiadało własną bibliotekę.

Po rewolucji 1917 r. Kościół katolicki w Jekaterynburgu, jak i wiele innych religijnych instytucji, przeszedł ciężkie próby. W 1922 r. na terenie ZSRR rozpoczęła się konfiskata dóbr kościelnych, w 1924 r. znacjonalizowano należące do społeczności katolickiej budynki przekazane przez Poklewskich ${ }^{5}$,

справочник. Вып. 1: А-Д, Екатеринбург 2011, s. 175-176; Т.П. Мосунова, А.В. Черноухов, Екатеринбург..., s. 14-17.

4 Т.П. Мосунова, Дворянский род уральских промышиленников Поклевских-Козелл, „Уральский Родовед” 1996, № 1, s. 74-87; taż, Новые материалы о польском роде Поклевских-Козелл, „Уральский Родовед” 2001, № 5, s. 86-92; А.Р. Ивонин, Сибирские предприниматели дореформенного периода: итрихи к историческому портрету, [in:] Личность в истории Сибири XVIII-XX веков. Сборник биографических очерков, под ред. А.К. Кириллова, Новосибирск 2007, s. 81-94; Л. Митрофанова, Водочный король Зауралья, „Урал” 2008, № 1, [online] http://magazines.russ.ru/ural/2008/1/mi34.html [dostęp 3.01.2018]; В.П. Микитюк, Т.П. Мосунова, Е.Г. Неклюдов, Род Поклевских-Козелл, Екатеринбург 2014.

5 Екатеринбургский римско-католический приход святой Анны. История, [online] 
zamknięto szkołę parafialną. 14 II $1930 \mathrm{r}$. na mocy rozporządzenia władz Swierdłowska (od 1924 r. tak brzmiała nowa nazwa Jekaterynburga) został zamknięty kościół pw. św. Anny, w którym urządzono bibliotekę. Proboszcz Franciszek Budrys został aresztowany, a następnie (w 1937 r.) rozstrzelany ${ }^{6}$.

Prawdopodobnie ok. 1924 r. razem z dworkiem po Poklewskich skonfiskowano książki z biblioteki parafialnej i z księgozbioru towarzystwa dobroczynności. Jak wynika z pieczątek na książkach, od 1928 r. należą do Swierdłowskiej Obwodowej (Regionalnej) Uniwersalnej Biblioteki Naukowej im. W.G. Bielińskiego (SOUBN; Свердловская областная универсальная научная библиотека имени Виссариона Григорьевича Белинского СОУНБ). Być może trafiły tam wcześniej, jednak dopiero w latach 1926-1927 znajdujące się w SOUBN książki zostały zinwentaryzowane i zarejestrowane $\mathrm{w}$ trakcie przeprowadzonej reorganizacji i remontu? ${ }^{7}$.

Obecnie druki w języku polskim nadal są przechowywane w oddziale rzadkich książek SOUBN ${ }^{8}$. Kolekcja liczy 250 tomów. Trzeba podkreślić, że nie na wszystkich książkach są pieczątki kościoła lub rzymsko-katolickiego towarzystwa dobroczynnego. O tym, że kolekcja zawiera woluminy z prywatnych zbiorów świadczą znajdujące się na nich znaki i napisy własnościowe. Na przykład na wielu stronach trzech tomów wydania dzieła Józefa Ignacego Kraszewskiego Polska w czasie trzech rozbiorów (Warszawa 1902-1903) ${ }^{9}$ znajduje się podpis „S. Baranowski”; na książce Kajetana Kraszewskiego Bartochowski: opowiadanie z końca XVIII wieku... (t. 2, Warszawa 1899, s. 67$)^{10}$ podpisano ołówkiem: „W. Siemaszko”, a strona tytułowa edycji Pism Adama Mickiewicza (Warszawa 1858) ${ }^{11}$ zawiera podpis „I.I. Игнатовский” oraz pieczątkę „Иван Иванович Игнатовский”. Natomiast na wewnętrznej stronie pokrywy dolnej oprawy książki Joachima Lelewela Stare pieniądze w 1824 roku [...] wykopane (Warszawa 1826) ${ }^{12}$ znajduje się ślepe tłoczenie:

\footnotetext{
http://www.ekatcatholic.ru/history.php [dostęp 3.01.2018]; Католический костёл св. Анны. Прошлое и настоящее, [online] http://www.1723.ru/forums/?showtopic=5959 [dostęp 3.01.2018]; В.П. Микитюк, Т.П. Мосунова, Е.Г. Неклюдов, Род Поклевских-Козелл, s. 196-197.

6 Екатеринбургский римско-католический приход святой Анны. Хроника событий нашего прихода, [online] http://ekatcatholic.ru/hrono/index [dostęp 3.01.2018].

С.3. Гомельская, Из истории Свердловской областной универсальной научной библиотеки им. В. Г. Белинского (1917-1926), [in:] Библиотеки Урала XVIII-XX вв. Вып. 1, Екатеринбург 2002, s. 38-46; taż, Свердловская Центральная окружная библиотека им. В.Г. елинского во второй половине 20-х годов XX века, [in:] Библиотеки Урала XVIII-XX вв. Вып. 4, Екатеринбург 2007, s. 39-46.

8 Отдел редких книг, [online] http://book.uraic.ru/howto/library/otdely/redkaya.htm [dostęp 04.08.2018].

9 SOUBN, sygn. 63.3 и9670, и9582, и9669.

10 SOUBN, sygn. 84(=415.3) и 8990 .

11 SOUBN, sygn. 84(4=415.3) и28263.

12 SOUBN, sygn. 63. 2 и140299.
} 
„M. Szokalski”. Niestety, nie udało mi się znaleźć żadnej informacji o wymienionych powyżej osobach, do których należały książki.

Losy książek zostały udokumentowane nie tylko w nazwiskach ich pierwotnych właścicieli, ale i w śladach pozostawionych na nich przez instytucje, do których trafiły. Na przykład na wewnętrznej stronie górnej pokrywy oprawy książki K. Stronczyńskiego Pieniądze Piastów... (Warszawa 1847) ${ }^{13}$ zapisano „Introligatornia Nowackiej w Włocławku” ${ }^{14}$, zaś na okładkach wszystkich wydań utworów J.I. Kraszewskiego znajduje się etykieta: „Переплетная В. Лебедихина и Ко. Екатеринбург угол Покровской и Солдатской улиц".

Polski księgozbiór w SOUBN tematycznie tworzy bardzo spójną, jednolitą kolekcję. W jej skład wchodzą książki historyczne, wśród których przeważają publikacje dotyczące historii prawa, numizmatyki, historii sztuki; duży blok tworzą prace z literaturoznawstwa i literatura piękna. Księgozbiór nie zawiera absolutnie wyjątkowych i szczególnie wartościowych pozycji, tym nie mniej są w nim bardzo ciekawe i rzadkie wydania. Najstarszą publikację stanowi książka Franciszka Pułaskiego Krotka Annotacya Seymow Warszawskich, Grodzieńskich, także Elekcyi y Koronacyi ... Krolow ... Polskich; Jana Kazimierza, Michała, Jana III, y Augusta II; tudziesz ... ich Kampaniy, ... odprawionych; publicznieyszych dzieiow, y rewolucyi ab anno 1648, ad annum 1733... (Lublin 1740, zob. fot. 1) ${ }^{15}$. Jest to dość rzadki zbiór historycznych aktów prawnych, odnoszących się do dziejów Rzeczypospolitej Obojga Narodów w okresie XVII-XVIII w. Temat analizy systemu prawnego Polski kontynuuje praca Teodora Ostrowskiego Inwentarz Nowy Praw, Traktatow $Y$ Konstytucyi Koronnych Y W. X. Lit. W Czasie Bez-Krolewia r. 1764. Y Za Panowania Nayiaśnieyszego Stanisława Augusta Do Roku 1780. Uchwalonych, Na Wzor Inwentarza Dawnieyszego Utożony... (Warszawa 1782, fot. 2) ${ }^{16}$. W kolekcji znajdują się też dwie rozprawy J. Lelewela: Stare pieniądze w roku 1824 w czerwcu blisko Plocka $w$ Trzebuniu wykopane (Warszawa 1826) ${ }^{17}$ i Cześć batwochwalcza Stawian i Polski (Poznań 1857) ${ }^{18}$. Do literatury numizmatycznej należą też m.in. książki: Feliksa Bentkowskiego Spis medalów polskich lub z dziejami krainy polskiej stycznych, w gabinecie król. Alex. Uniwersytetu $w$ Warszawie znajdujących się, tudzież ze zbiorów i pism rozmaitych lub podań zebrany i porzadkiem lat ułożony... (Warszawa 1830) ${ }^{19}$, Edwarda

13 SOUBN, sygn. 63. 2 и26635.

14 Na temat introligatorni Nowackiej zob. K. Rulka, Zapiski do dziejów introligatorstwa we Włocławku, ,Studia Włocławskie” 2013, t. 15, s. 265.

15 SOUBN, sygn. 63.3(4) и 10962.

16 SOUBN, sygn. 67.3 и41145.

17 SOUBN, sygn. 63.2 и 140299.

18 SOUBN, sygn. 86.3 и28241.

19 SOUBN, sygn. 63.2 и41155. 
Tomasza Massalskiego Tablice porównawcze wszystkich wiadomych monet, wag i miar, wyrachowanych na monety, wagi i miary nowe francuskie, nowe polskie i rossijskie... (Petersburg 1834) ${ }^{20}$, Kazimierza Władysława Stężyńskiego Bandtkie Numismatyka krajowa... (Warszawa 1839) ${ }^{21}$.

Znaczną grupę stanowią publikacje dotyczące historii Polski i powszechnej, na przykład prace Juliana Bartoszewicza z lat 1870-1880; wielotomowa seria wydawnicza Dzieje Powszechne Illustrowane, która ukazała się w Wiedniu nakładem Franciszka Bondy (tomy z lat 1894-190022); Historia XIX stulecia: dzieje polityki, literatury, sztuki, nauki, przemystu i t. p. opracowane na podstawie najnowszych badań i objaśnione licznemi ilustracjami opublikowana pod redakcją Aleksandra Czechowskiego w Warszawie w $1901 \mathrm{r}$. (w dwóch tomach ${ }^{23}$ ) $\mathrm{i}$ in.

Wśród utworów literatury pięknej znajdującej się w polskiej kolekcji jednym z najwcześniejszych wydań jest zbiór wierszy J.I. Kraszewskiego Poezje... (Wilno 1838, t. 124). SOUBN posiada dość dużo edycji utworów tego pisarza. Są to zbiory jego dzieł, wydane w różnym czasie: w latach 70. i 90. XIX w. oraz w pierwszym dziesięcioleciu XX w. (fot. 3). W skład kolekcji wchodzą również tomy z edycji zbiorowych utworów A. Mickiewicza, także publikowanych w różnych latach; najwcześniejsze wydanie pochodzi z 1858 r. ${ }^{25}$ (fot. 4). Ponadto warto wymienić Pisma Henryka Sienkiewicza opublikowane w Warszawie w 1899-1906 r. (81 wol.) oraz różne wydania utworów Elizy Orzeszkowej, Juliusza Słowackiego, Bolesława Prusa, Zygmunta Krasińskiego. Do zbioru beletrystyki należą też książki, które zostały opublikowane przez wydawnictwo „Trybuna” Centralnego Komitetu Wykonawczego Grup Socjaldemokracji Królestwa Polskiego i Litwy w Rosji: Pieśni wolnego ducha. Zbiór poezji rewolucyjnych (Piotrogród 1917) ${ }^{26}$, Pieśni zwycięstwa. Zbiór wierszy rewolucyjnych wydany w pierwsza rocznicę dyktatury proletariatu w Rosji (Moskwa 1918) ${ }^{27}$.

Publikacje literaturoznawcze reprezentuje m.in. tłumaczenie na język polski pracy Fryderyka Schillera Listy o wychowaniu estetycznem czlowieka tudzież rozprawy o wzniostości, o sztuce tragicznej, o moralnej korzyści estetycznych obyczajów (Warszawa 1843) ${ }^{28}$, a także czterotomowa Historia

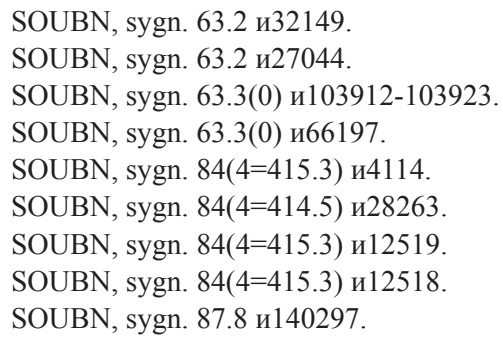


literatury polskiej Piotra Chmielowskiego (Warszawa 1899-1900) ${ }^{29}$; drugie wydanie pięciotomowej Historii literatury polskiej Stanisława Tarnowskiego (1903-1904) ${ }^{30}$ oraz praca Ferdynanda Hösicka O Stowackim, Krasińskim i Mickiewiczu. Studia historyczno-literackie (Kraków1895) ${ }^{31}$.

Kolekcja książek SOUBN niewątpliwie odzwierciedla różnorodność zainteresowań dawnej społeczności polskiej Jekaterynburga. Oprócz literatury naukowej i pięknej zawiera albumy artystyczne i zbiory pocztówek: Album Jana Matejki wydany w opracowaniu Kazimierza Władysława Wójcickiego (Warszawa 1876) $^{32}$; Album Henryka Sienkiewicza - Pan Wołodyjowski z rysunkami Stanisława Batowskiego-Kaczora, Juliusza Kossaka i Władysława Tetmayera (Warszawa 1900) ${ }^{33}$; Kraków (Kraj w Obrazach) opublikowany przez Wydawnictwo Salonu Malarzy Polskich w Krakowie w 1912 r. ${ }^{34}$ oraz książki kucharskie: Piekarnia i cukiernia wytworna i gospodarska... Marty Norkowskiej (Warszawa 1908) ${ }^{35}$; Domowa kuchnia. Skarbczyk kulinarny potraw mięsnych, jarskich, ciast, marynat $i$ ważniejszych sekretów gospodarskich Aliny Gniewkowskiej (Kijów 1917) ${ }^{36}$.

Wymienione wyżej pozycje z listy polskich wydawnictw znajdujących się w zbiorach swierdłowskiej biblioteki (SOUBN) dają reprezentatywny obraz zawartości polskiej kolekcji.

Niewielka, bo licząca zaledwie 17 egzemplarzy, ale bardzo ciekawa jest kolekcja książek w języku polskim przechowywana w Swierdłowskim Obwodowym (Regionalnym) Muzeum Krajoznawczym (SOMK; Свердловский областной краеведческий музей - COKM) ${ }^{37}$. 13 książek z tej kolekcji pochodzi ze zbiorów biblioteki Uralskiego Towarzystwa Miłośników Nauk Przyrodniczych (UTMNP; Уральское общество любителей естествознания УОЛЕ $)^{38}$, założonego w $1870 \mathrm{r}$. z inicjatywy intelektualnej elity Jekaterynburga

29 SOUBN, sygn. 83.3(4) и9753, и103879-103982, и103997.

30 SOUBN, sygn. 83.3(4) и140296, и140298.

31 SOUBN, sygn. 83.3(4) и3983, и9682.

32 SOUBN, sygn. 85.14(4) и28481.

33 SOUBN, sygn. 85.15(4) и 4829.

34 SOUBN, sygn. 26.89(4) и136706.

35 SOUBN, sygn. 63.3(2) и12041.

36 SOUBN, sygn. 36.99 и62907.

37 Informacje na temat biblioteki SOMK można znaleźć na stronie Muzeum, Информационно-библиотечный центр, [online] http://uole-museum.ru/museums/informatsionno-bibliotechnyj-tsentr/ [dostęp 15.12.2017].

38 Л.И. Зорина, Уральское общество любителей естествознания. 1870-1929. Из истории науки и культуры Урала, Екатеринбург 1996, Ученые Записки, Т. 1, s. 208; Т. Моsunowa, Swierdłowskie Regionalne Muzeum Krajoznawcze w XXI wieku: ślepa uliczka czy nowe możliwości?, „Rocznik Museum Wsi Mazowieckiej w Sierpcu” 2011, t. 2, s. 150-157, [online] http://mazowsze.hist.p1/34/Rocznik_Muzeum_Wsi_Mazowieckiej_w_Sierpcu/714/2011/24952/ [dostęp 15.12.2017]. 
w celu zintegrowania jej działalności naukowo-badawczej, przeprowadzenia studiów w różnych dziedzinach i wsparcia rozwoju regionu. Członkowie Towarzystwa prowadzili badania z meteorologii i fenologii, z geologii, mineralogii, paleontologii, geografii, zajmowali się ochroną przyrody, botaniką, zoologią, statystyką, medycyną, etnografią, archeologią, historią. Przy UTMNP działało muzeum historyczno-etnograficzne i biblioteka. Na początku XX w. biblioteka Towarzystwa była jedną z największych na Uralu. Przed 1917 r. liczyła 60000 woluminów $^{39}$, z czego kilka tysięcy książek w językach obcych ${ }^{40}$. Na zbiory biblioteki składały się kolekcje prywatne wielu byłych członków organizacji, przekazane nieodpłatnie po ich śmierci lub sprzedane Towarzystwu przez spadkobierców. Po reorganizacji UTMNP w 1929 r. biblioteka została przekazana Muzeum Krajoznawczemu w Swierdłowsku, utworzonemu na bazie zbiorów muzeum historyczno-etnograficznego Towarzystwa.

Część pochodzących z biblioteki UTMNP książek w języku polskim a obecnie znajdujących się w Muzeum Krajoznawczym wcześniej należała do wybitnych działaczy nauki i kultury rosyjskiej. Świadczą o tym ekslibrisy lub zapisy i inne znaki własnościowe byłych właścicieli.

W zbiorach Muzeum znajdują się m.in. książki z biblioteki Wasilija Nikiticza Tatiszczewa (Василий Никитич Татищев, 1686-1750), wybitnego działacza państwowego, pierwszego rosyjskiego profesjonalnego historyka, który był założycielem kilku uralskich fabryk i pierwszych publicznych szkół górniczych w uralskich zakładach, twórcą Ogólnouralskiego Zarządu Zakładów Górniczych (Syberyjskie Kierownictwo Górnicze). Tatiszczew wniósł wielki wkład w skompletowanie pierwszej biblioteki publicznej w Jekaterynburgu, do której książki zgodnie z jego dyspozycją specjalnie sprowadzano z Petersburga. Zbiory prywatne Tatiszczewa były jednymi z najbardziej znaczących w Rosji w pierwszej połowie XVIII w., licząc ogółem 781 książek, w tym 714 w językach obcych. Księgozbiór Tatiszczewa zawierał kilkanaście książek w języku polskim, którym władał. W kolekcji UTMNP znalazło się 181 woluminów z biblioteki tego wybitnego uczonego, które trafiły tam w $1900 \mathrm{r}^{41}$ Wśród nich - dzieło biskupa warmińskiego Marcina Kromera O Sprawach, Dzieiach, Y Wszystkich Inszych Potocznosciach Koronnych Polskich: Kśiag XXX..., wytłoczone w Krakowie w drukarni Mikołaja Loba w 1611 r. ${ }^{42}$ (fot. 5). Tę i szereg innych druków w języku polskim i niemieckim Tatiszczew kupił podczas pobytu w Toruniu i Gdańsku

\footnotetext{
39 Информационно-библиотечный центр....

40 Л.И. Зорина, Уральское общество..., s. 144.

41 Каталог книг В.Н. Татищева и первой библиотеки Екатеринбурга в фондах Свердловского областного краеведческого музея, сост. А.М. Сафронова, В.Н. Оносова, Екатеринбург 2005.

42 SOMK, sygn. СМ-14344/4707 ПИ-4707.
} 
w $1717 \mathrm{r}^{43} \mathrm{Z}$ jego inicjatywy w Jekaterynburgu przełożono dzieło Kromera na język rosyjski, jednak przetłumaczono nie polską, tylko łacińską edycję opublikowaną w 1568 r. w Bazylei, natomiast tekstem polskiego wydania tłumacz prawdopodobnie posłużył się podczas dokonania korekty tłumaczenia. Tatiszczew planował wydanie rosyjskiego przekładu pracy Kromera drukiem, jednak niestety nie uzyskał wsparcia Rosyjskiej Akademii Nauk ${ }^{44}$. Należy wszak zaznaczyć, że dzieła Kromera, a zwłaszcza jego sarmacka interpretacja teorii pochodzenia Słowian, cieszyła się dużą popularnością w XVII-XVIII w. w Rosji. Druga książka w języku polskim z biblioteki W.N. Tatiszczewa to Żywoty Swiętych Ten Apollo Pieie Iak Ci Działali Niech Tak Kozdy Dzieie... ${ }^{45}$, utwór napisany przez arcybiskupa diecezji czernihowskiej, administratora kijowskiej metropolii prawosławnej Łazarza Baranowicza ${ }^{46}$ a wydany drukiem w typografii Ławry Kijowsko-Pieczerskiej w 1670 r. Na ostatniej stronie egzemplarza książki znajduje się zapis Tatiszczewa, informujący o tym, że nabył ją w 1720 r. w Moskwie za 56 kopiejek (fot. 6).

Trzy polskie książki z kolekcji UTMNP należały do znanego uralskiego pisarza, krajoznawcy, jednego z organizatorów Towarzystwa - Narkiza Konstantynowicza Czupina (Наркиз Константинович Чупин, 1824-1882). W latach 1907-1908 jego biblioteka zawierająca 1447 woluminów została kupiona przez UTMNP $^{47}$. Wśród tych książek znajduje się drugie polskie wydanie dzieła Giovanniego Botera Relatice Powszechne Abo Nowiny Pospolite ... Rozłożone Ná Pięć Części... wytłoczone w 1613 r. w Krakowie w drukarni M. Loba ${ }^{48}$ (fot. 7). W egzemplarzu Muzeum zachowały się pozostałe dwie części tego dzieła druga (Zamyka się Hydrographia, to iest, opisanie morza w pospolitości: także wyspow, y peninsul, aż do tego czasu znalezionych) i trzecia (Zamyka się Monarchologia, to iest, daie się sprawa o przednieyszych monarchach na świecie).

Kolejne trzy polskie wydawnictwa trafiły do UTMNP z biblioteki Władimira Władimirowicza Gołubcowa (Владимир Владимирович Голубцов, 1855-1892), badacza rosyjskiej genealogii i heraldyki, uralskiego krajoznawcy.

43 А.М. Сафронова, Документы о переводе труда М. Кромера по истории Польши по заказу В. Н. Татищева в 1735 г., [in:] Архивы России и Польши: история, проблемь u перспективы развития = Archiwa Rosji i Polski: historia, problemy i perspektywy rozwoju. Сборник научных трудов, под общ. ред. Л. Мазур и Я. Лосовски, Екатеринбург 2013, s. 24-25.

44 Tamże, s. 30-34.

45 SOMK, sygn. СМ-14344/4611 ПИ-4611.

46 Лазарь (Баранович), [in:] Русский биографический словарь. Т. 10: Лабзина-Ляменко, под ред. Н.Д. Чечулина, М. Г. Курдюмова, Санкт-Петербург 1914, s. 40-43.

47 С.3. Гомельская, Библиотека Н.К. Чупина, [in:] Уральский библиофил, сост. Ю.А. Горбунов, Свердловск 1984, s. 113-125; Е.П. Пирогова, История приобретения библиотеки Н.К. Чупина Уральским обществом любителей естествознания, [in:] Третьи Чупинские краеведческие чтения: материаль конференции (Екатеринбург, 16-17 февраля 2006 г.), сост. Т.А. Колосова, Екатеринбург 2006, s. 29-36.

48 SOMК, sygn. СМ-22697 ПИ-11839. 
W 1887 r. zbiory Gołubcowa liczyły około 8000 woluminów. Po śmierci właściciela księgozbiór odziedziczyli jego brat, wdowa i syn. W 1917 r. duża część książek, która wcześniej należała do rodzinnej biblioteki Gołubcowów, znalazła się w Krasnoufimskim Muzeum Krajoznawczym (Krasnoufimsk jest małym miastem na Uralu, w pobliżu którego znajdowała się posiadłość Gołubcowów), a w 1925 r. książki te zostały przekazane UTMNP ${ }^{49}$. Niestety, literatury obcej z tej biblioteki dotychczas nikt nie zbadał. Obecnie w bibliotece SOMK znajdują się następujące książki w języku polskim: drugi tom serii Dzieła Dramatyczne Williama Shakespeare (Szekspira) redagowanej przez J.I. Kraszewskiego, wydany w Warszawie w 1875 r. i zawierający Tragedie ${ }^{50}$ (seria ilustrowana 545 drzeworytami Henry'ego Courtneya Selousa) w przekładach Stanisława Koźmiana, Józefa Paszkowskiego i Leona Ulricha; źródła do dziejów rodziny Paców, magnackiego rodu z Wielkiego Księstwa Litewskiego, wydane przez Józefa Wolffa - Pacowie: Materiaty historyczno-genealogiczne (Petersburg 1885) ${ }^{51}$. Ze zbiorów W. Gołubcowa pochodzi również drugi numer „Biblioteki Warszawskiej. Pisma poświęconego naukom, sztukom i przemysłowi" z $1882 \mathrm{r}^{52} \mathrm{Z}$ czasopismem, które ukazywało się w latach 1841-1914, współpracowało wiele wybitnych osób ze świata nauki i kultury polskiej, m.in. F. Bentkowski, Tadeusz Korzon i Henryk Struve.

Właścicielem trzech kolejnych publikacji w języku polskim, które znalazły się w zbiorach UTMNP, był uralski archeolog z przełomu XIX i XX w. Aleksander Francewicz Komies (Александр Францевич Комес). Dwie z nich dotyczą historii Polski. Są to drugie wydanie Wiadomości z historii polskiej zastosowane do użytku pensji i szkót ptci żeńskiej Łukasza Gołębiowskiego (Warszawa 1830) (53 $^{5}$ oraz trzecia edycja Rysu chronologiczno-historycznego państw nowożytnych od $V$. wieku do dziś dnia, z kilkunastu mapkami i kilkudziesięciu genealogiami Aleksandra Zdanowicza (Wilno 1853) ${ }^{54}$. Trzecia zaś stanowi tłumaczenie $\mathrm{z}$ języka niemieckiego podręcznika mitologii greckiej i rzymskiej autorstwa teologa Augusta Heinricha Petiscusa Olimp czyli Mitologia greków i rzymian, z dodaniem wiadomości o bogach Egiptu, Indii i Krain Pótnocy, którego dokonała Anastazja Dzieduszycka. Książka ukazała się w drukarni Maurycego Orgelbranda w Warszawie w 1875 r. ${ }^{55}$

49 Е.П. Пирогова, Уральские помещики Голубиовы и их родовая библиотека, [in:] Книжные собрания российской провинции: проблемы реконструкции. Сборник научных трудов, [отв. ред. Н.А. Мудрова], Екатеринбург 1994, s. 211-242.

50 SOMК, sygn. СМ-28549/94 ПИ-15137.

51 SOMК, sygn. СМ-27701/45 ПИ-13476.

52 SOMK, sygn. СМ-28543/47 ПИ-14830.

53 SOMК, sygn. СМ-27701/78 ПИ-13509.

54 SOMК, sygn. СМ-28672/57 ПИ-15829.

55 SOMК, sygn. СМ-14344/4041 ПИ-4041. 
Jedna książka z kolekcji UTMNP pochodzi z biblioteki innego uralskiego intelektualisty, Niemca z pochodzenia, Aleksieja Iwanowicza Kroneberga (Алексей Иванович Кронеберг, 1828-1880), który w różnych latach pełnił funkcję przewodniczącego wierchoturskiego zarządu ziemskiego, pomocnika zarządcy niżnietagilskiego okręgu górniczego, sędziego pokoju okręgu jekaterynburgskiego oraz był tłumaczem i muzykiem ${ }^{56}$. Jest to pierwsza część Początków algebry nauczyciela matematyki w Liceum Wołyńskim Grzegorza Hreczyny (Krzemieniec 1830) $)^{57}$.

Oprócz wymienionych wyżej woluminów ze zbiorów UTMNP, które pochodzą z prywatnych kolekcji byłych członków tej organizacji, jedna książka w języku polskim opatrzona jest wyłącznie pieczątką Towarzystwa. Jest to wydana w Berlinie w 1910 r. z przedmową Franciszka Alberta Schultza Biblia to iest, wszystko Pismo Święte Starego i Nowego Przymierza wedtug edycyi Biblii Gdańskiey w roku 1632 wydaney ułożone a teraz dla pożytku zborów polskich protestanckich podtug Biblii Królewieckiey w roku 1738 wydaney na nowo przedrukowan ${ }^{58}$.

Cztery książki w języku polskim znajdujące się obecnie w zbiorach Muzeum Krajoznawczego nie należały do dawnej biblioteki UTMNP. Nie są opatrzone żadnymi pieczęciami, ekslibrisami ani innymi znakami czy wpisami proweniencyjnymi, niemożliwe jest więc ustalenie, w jaki sposób znalazły się w Jekaterynburgu. Są to: Gramatyka hebrajska... Luigiego Chiariniego w przekładzie Piotra Chlebowskiego (Warszawa 1826) ${ }^{59}$; Ród Gedimina. Dodatki i poprawki do dziet K. Stadnickiego: "Synowie Gedymina», "Olgierd $i$ Kiejstut» $i$ «Bracia Władysława Jagietly» autorstwa J. Wolffa (Kraków 1886) ${ }^{60}$; siódme wydanie popularnego podręcznika (pierwsza edycja w 1905 r.) Stylistyki i teorii literatury... Henryka Galle (Warszawa 1917) ${ }^{61}$. Interesujące źródło historyczne stanowi obszerny Kalendarz komunistyczny na rok 1920 (wydanie Moskwa-Smoleńsk 1919) ${ }^{62}$, który został opracowany przez Wydawnictwo Biura Polskiego przy Centralnym Komitecie Komunistycznej Partii Rosji. Kierownikiem Biura w tym okresie był Feliks Dzierżyński. Zgodnie z informacją podaną przez wydawcę była to pierwsza publikacja tego typu w języku polskim wydana na terenie Rosji Sowieckiej.

56 В.П. Микитюк, Алексей Иванович Кронеберг, [in:] Нижний Тагил в лицах. Общественные деятели Тагила XIX - начала XX века. Пособие по историческому краеведению, отв. ред. и сост. Е.Г. Неклюдов, Нижний Тагил 1998, s. 44-55.

57 SOMK, sygn. CM-28790/78.

58 SOMК, sygn. СМ-14344/3842 ПИ-3842.

59 SOMK, sygn. СМ-28205/6 ПИ-13817.

60 SOMK, sygn. СМ-28543/11 ПИ-14794.

61 SOMК, sygn. СМ-28543/79 ПИ-14862.

62 SOMК, sygn. СМ-28540/29 ПИ-14569. 
Kolejne trzy książki w języku polskim zostały znalezione przeze mnie w bibliotece Uralskiego Państwowego Uniwersytetu Prawa (Уральский государственный юридический университет) ${ }^{63}$. Są to publikacje prawnicze odpowiadające profilowi uczelni: trójjęzyczny Zbiór dawnych dyplomatów i aktów miast: Wilna, Kowna, Trok, prawosławnych monasterów, cerkwi $i$ w różnych sprawach (Wilno 1843) ${ }^{64}$; rosyjsko-polski Zbiór przepisów administracyjnych Królestwa Polskiego... (Warszawa 1867, cz. 2, t. 13) ${ }^{65}$ oraz również dwujęzyczny Zbiór praw. Postanowienia i rozporządzenia rzqdu w guberniach Królestwa Polskiego obowiazujące... (Warszawa 1886) ${ }^{66}$. Książki te na początku znajdowały się w bibliotece Uralskiego Instytutu Przemysłowego, a po utworzeniu w 1936 r. Swierdłowskiego Instytutu Prawa prawdopodobnie zostały przekazane do jego biblioteki, o czym świadczą pieczątki na książkach z 1936 i 1948 r.

W Centralnej Bibliotece Naukowej Uralskiego Oddziału Rosyjskiej Akademii Nauk (Центральная научная библиотека Уральского отделения Российской Академии наук) w Jekaterynburgu znalazłam natomiast 11 numerów warszawskiego czasopisma „Izys Polska” z lat 1821-1824 ${ }^{67}$. Periodyk ten był jednym z pierwszych polskich czasopism technicznych, którego celem było upowszechnienie w kraju wynalazków i innych światowych osiągnięć w dziedzinie rzemiosła, przemysłu i techniki ${ }^{68}$. Na podstawie pieczątek można wnioskować, że najpierw numery te znajdowały się w bibliotece Moskiewskiego Instytutu Stali i Stopów (placówka o tradycji przedwojennej nosząca tę nazwę od 1962 r. $)^{69}$. Na razie nie udało się ustalić, kiedy trafiły na Ural.

Wszystkie zidentyfikowane książki i periodyki w języku polskim zostały zarejestrowane w katalogach jekaterynburgskich bibliotek. Jednak badaniem egzemplarzy i ich historią nikt się dotąd specjalnie nie zajmował. Dalsze poszukiwanie

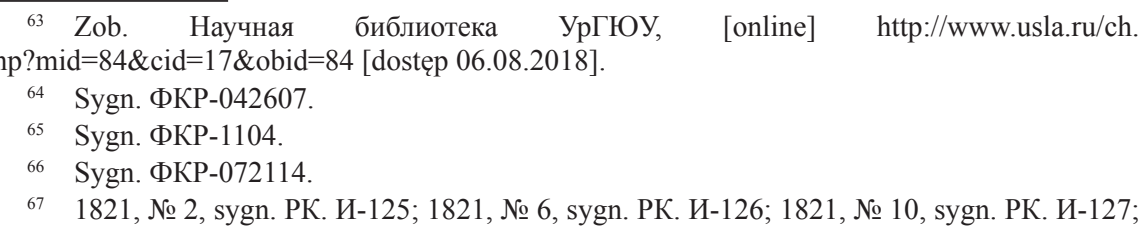
1822, № 12, sygn. РК. И-128; 1823, № 4, sygn. РК. И-118; 1824, № 6, sygn. РК. И-119; 1924, № 7, sygn. РК. И-121; 1824, № 8, sygn. РК. И-120; 1824, № 9, sygn. РК. И-122; 1824, № 10, sygn. РК. И-123; 1824, № 12, sygn. РК. И-124.

68 Zob. K. Schabowska, Metody zapisu konstrukcji mechanicznych w czasopiśmie «Izys Polska» (1820-1828), „Analecta” 2004, z. 1-2, s. 185-199, [online] http://bazhum.muzhp.pl/media// files/Analecta_studia_i_materialy_z_dziejow_nauki/Analecta_studia_i_materialy_z_dziejow_nauki-r2004-t13-n1_2_(25_26)/Analecta_studia_i_materialy_z_dziejow_nauki-r2004-t13-n1_2_ (25_26)-s185-199/Añalecta_studia_i_materialy_z_dziejow_nauki-r2004-t13-n1_2_(25_26)-s185199.pdf [dostęp 06.08.2018].

69 Zob. na stronie Narodowego Uniwersytetu Naukowo-Technologicznego MISIS, [online] http://misis.ru/university/about/ [dostęp 06.08.2018]. 
polskich książek i czasopism w bibliotekach Jekaterynburga prawdopodobnie doprowadzi do nowych odkryć, również w zakresie ich dziejów oraz rekonstrukcji dróg, jakimi docierały do jekaterynburgskich zbiorów. Jednak już teraz na podstawie dotychczasowych studiów proweniencyjnych można stwierdzić, że literatura polska była obecna w księgozbiorach nie tylko Polaków i osób polskiego pochodzenia żyjących w tym mieście w XVIII-XX w., ale również znana była w rosyjskich środowiskach intelektualnych na Uralu.

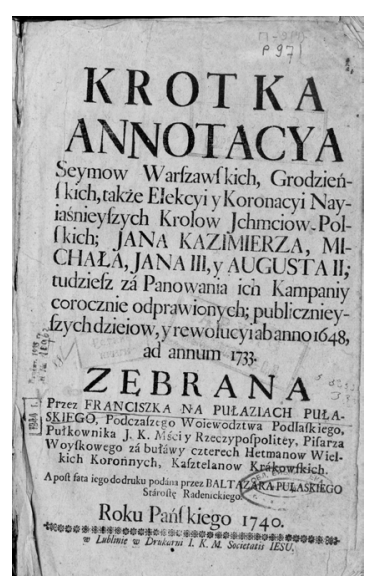

Fot. 1. Strona tytułowa książki

F. Pułaskiego Krotka Annotacya Seymow Warszawskich... Źródło: SOUBN, sygn. 63.3(4)и 10962.

Zdjęcie: I. Poczyńskaja

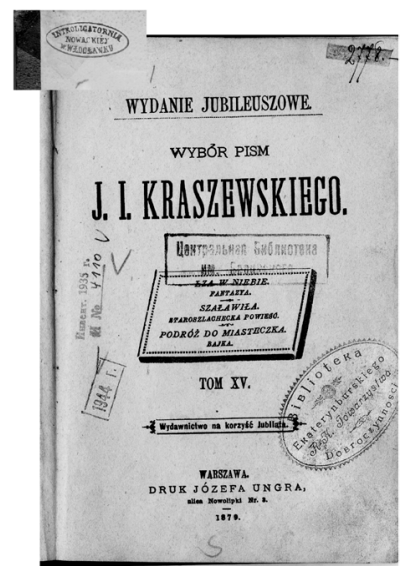

Fot. 3. Strona tytułowa i pieczątka na wewnętrznej stronie górnej pokrywy oprawy książki J.I. Kraszewskiego Wybór pism. Źródło: SOUBN, sygn. 84(4=414.3)и4110. Zdjęcie:

I. Poczyńskaja

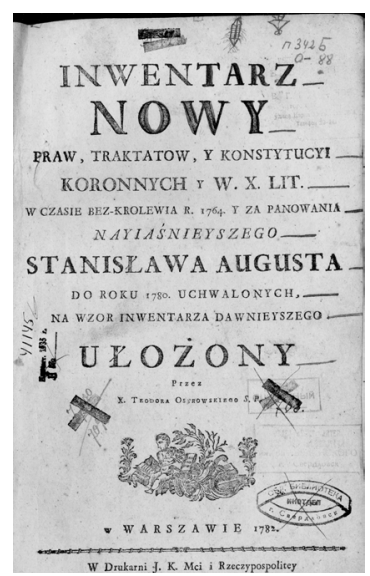

Fot. 2. Strona tytułowa książki T. Ostrowskiego Inwentarz Nowy... Źródło: SOUBN, sygn. 67.3.n41145.

Zdjęcie: I. Poczyńskaja

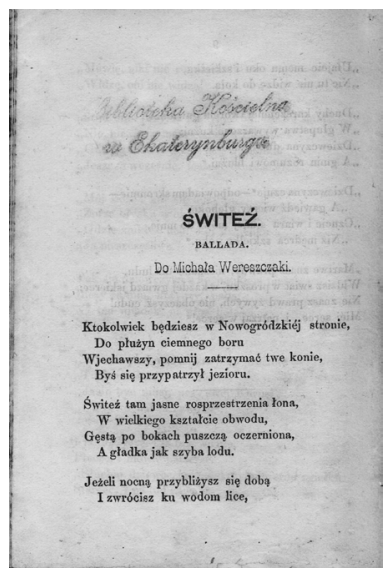

Fot. 4. Pieczątka w Pismach

A. Mickiewicza. Źródło: SOUBN, sygn. 84(4=414.5)и28263.

Zdjęcie: I. Poczyńskaja 


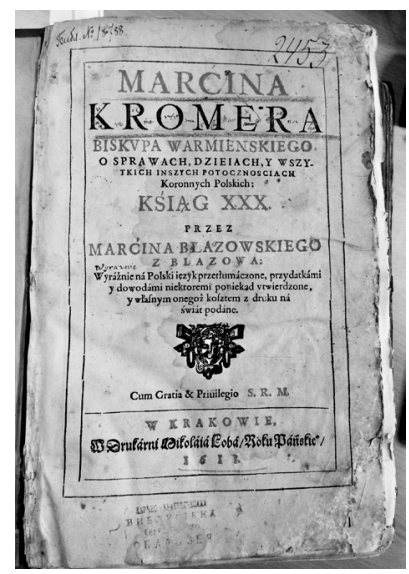

Fot. 5. Strona tytułowa książki M. Kromera O Sprawach... Źródło: SOMK, sygn. СM-14344/4707 ПИ4707. Zdjęcie: I. Poczyńskaja

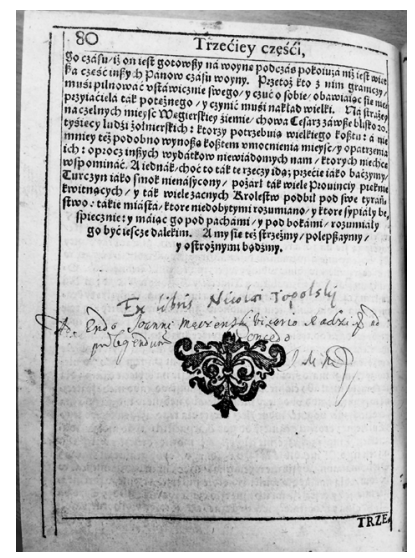

Fot. 7. Wpisy proweniencyjne w książce Relatice Powszechne... G. Botera, cz. 3, s. 80. Źródło: SOMK, sygn. CM-22697 ПИ-11839. Zdjęcie: I. Poczyńskaja

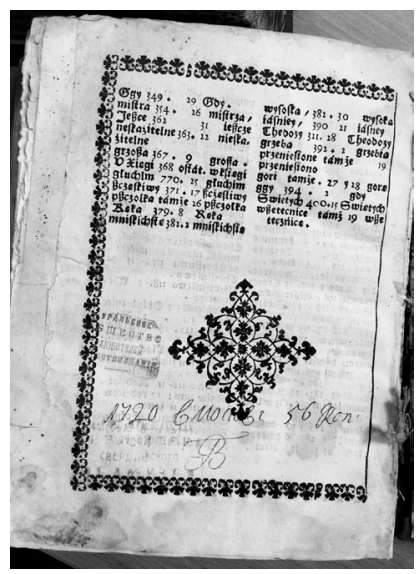

Fot. 6. Autograf W.N. Tatiszczewa w książce Żywoty Swiętych... Źródło: SOMК, sygn. СМ-14344/4611 ПИ-4611. Zdjęcie: I. Poczyńskaja 


\section{Bibliografia}

Бессонов М.С., История северного Урала в лииах (1589-1917). Биографический справочник. Вып. 1: А-Д, Екатеринбург 2011, s. 175-176.

Черноухов Э.А., Врачи - поляки на горных заводах Урала в XIX в., „Вопросы Истории" 2014, № 4, s. 148-152.

Екатеринбургский римско-католический приход святой Анны. История, [online] http://www.ekatcatholic.ru/history.php [dostęp 3.01.2018].

Гомельская С.З., Библиотека Н. К. Чупина, [in:] Уральский библиофил, сост. Ю.А. Горбунов, Свердловск 1984, s. 113-125.

Гомельская С.3., Из истории Свердловской областной универсальной научной библиотеки им. В. Г. Белинского (1917-1926), [in:] Библиотеки Урала XVIII-ХХ вв. Вып. 1, Екатеринбург 2002, s. 38-46.

Гомельская С.3., Свердловская Центральная окружная библиотека им. В.Г. Белинского во второй половине 20-х годов XX века, [in:] Библиотеки Урала XVIII-XX вв. Вып. 4, Екатеринбург 2007, s. 39-46.

Ивонин А.Р., Сибирские предприниматели дореформенного периода: итрихи к историческому портрету, [in:] Личность в истории Сибири XVIII-XX веков. Сборник биографических очерков, под ред. А.К. Кириллова, Новосибирск 2007, s. 81-94.

Каталог книг В.Н. Татищева и первой библиотеки Екатеринбурга в фондах Свердловского областного краеведческого музея, сост. А.М. Сафронова, В.Н. Оносова, Екатеринбург 2005.

Католический костёл св. Анньл. Прошлое и настоящее, [online] http://www.1723.ru/ forums/?showtopic=5959 [dostęp 3.01.2018].

Лазарь (Баранович), [in:] Русский биографический словарь. Т. 10: Лабзина-Ляменко, под ред. Н.Д. Чечулина, М. Г. Курдюмова, Санкт-Петербург 1914, s. 40-43.

Микитюк В.П., Алексей Иванович Кронеберг, [in:] Нижний Тагил в лицах. Общественные деятели Тагила ХІХ-начала ХХ века. Пособие по историческому краеведению, отв. ред. и сост. Е.Г. Неклюдов, Нижний Тагил 1998, s. 44-55.

Микитюк В.П., Мосунова Т.П., Неклюдов Е.Г., Род Поклевских-Козелл, Екатеринбург 2014.

Митрофанова Л., Водочный король Зауралья, „Урал” 2008, № 1, [online] http://magazines.russ.ru/ural/2008/1/mi34.html [dostęp 3.01.2018].

Mosunowa T., Swierdłowskie Regionalne Muzeum Krajoznawcze w XXI wieku: ślepa uliczka czy nowe możliwości?, „Rocznik Museum Wsi Mazowieckiej w Sierpcu” 2011, t. 2, s. 150-157.

Мосунова Т.П., Дворянский род уральских промышленников Поклевских-Козелл, „Уральский Родовед” 1996, № 1, s. 74-87.

Мосунова Т.П., Новые материаль о польском роде Поклевских-Козелл, „Уральский Родовед” 2001, № 5, s. 86-92. 
Мосунова Т.П., Черноухов А.В., Екатеринбург и его окрестности в жизни поляков в XVIII - начале XX в., [in:] Архивы России и Польши: история, проблемь и перспективы развития. Сборник научных трудов, под общ. ред. Л. Мазур и Я. Лосовски, Екатеринбург 2012, s. 13-22.

Пирогова Е.П., История приобретения библиотеки Н.К. Чупина Уральским обществом любителей естествознания, [in:] Третьи Чупинские краеведческие чтения: материаль конференции (Екатеринбург, 16-17 февраля 2006 г.), сост. Т.А. Колосова, Екатеринбург 2006, s. 29-36.

Пирогова Е.П., Уральские помещчики Голубияовы и их родовая библиотека, [in:] Книжные собрания российской провинции: проблемы реконструкции. Сборник научных трудов, [отв. ред. Н.А. Мудрова], Екатеринбург 1994, s. 211-242.

Поляки в Пермском крае: очерки истории и этнографии, под ред. А.В. Черныха, Санкт-Петербург 2009.

Рязанов С.М., Поляки на полицейской службе в Пермской губернии (конеи XIX начало ХХ в.), „Вестник Пермского Университета” 2015, № 4, s. 110-119.

Rulka K., Zapiski do dziejów introligatorstwa we Włocławku, „Studia Włocławskie” 2013, t. 15, s. 262-270.

Сафронова А.М., Документы о переводе труда М. Кромера по истории Польши по заказу В. Н. Татищева в 1735 г., [in:] Архивы России и Польши: история, проблемы и перспективы развития = Archiwa Rosji i Polski: historia, problemy i perspektywy rozwoju. Сборник научных трудов, под общ. ред. Л. Мазур и Я. Лосовски, Екатеринбург 2013, s. 22-42.

Сафронов А.А., Поляки на Урале в конще XIX в. (по материалам первой всеобщей переписи населения Российской империи 1897 г.). Материаль IV Международной научно-практической конференции, посвященной 20-летию подготовки документоведов в Уральском федеральном университете, Екатеринбург, 1-4 ноября 2012 2., [in:] Документ. Архив. Иистория. Современность, Екатеринбург 2012, s. 256-260, [online] http://elar.urfu.ru/hadle/10995/35508 [dostęp 3.01.2018].

Schabowska K., Metody zapisu konstrukcji mechanicznych w czasopiśmie «Izys Polska» (1820-1828), „Analecta” 2004, z. 1-2, s. 185-199.

Зорина Л.И., Уральское общество любителей естествознания. 1870-1929. Из истории науки и культуры Урала, Екатеринбург 1996, Ученые Записки, Т. 1. 
Greta Lemanaite

Jagiellońskie Centrum Językowe

Uniwersytet Jagielloński, Kraków, Polska

greta.deprati@gmail.com

ORCID 0000-0002-1142-1287

http://doi.org/10.33077/zbkh.2018.12.lemanaite

\title{
Ze Szwecji do Polski. Dary Henryka Bukowskiego w bibliotekach krakowskich
}

\author{
Abstract \\ From Sweden to Cracow. Henryk Bukowski's gifts \\ in libraries of Cracow
}

One of the participants of the 1863 uprising, Henryk Bukowski, who later emigrated and settled down in Sweden, was well-known not only to the Polish expatriate community as a great antiquarian. H. Bukowski is also famous for his great work for the foundation, patronizing and donating the Polish National Museum in Rapperswil, which was not his sole activity. Being a great bibliophile, on every possible occasion he presented many valuable books to different libraries and other institutions in exile and in the country as well. It is known that in the years 1887-1890 The Academy of Science in Cracow received a collection of approximately six hundred books, accompanied by a catalogue prepared by Bukowski himself. It is worth mentioning that the Jagiellonian Library was given several dozen books, important for the Polish culture, and several hundred brochures. Also, the National Museum in Cracow has a big collection of artefacts given by the collector from Sweden. None of those collections have been explored before. The article is based on the correspondence between Bukowski and the directors of all three institutions in Cracow donated by the Swedish antiquarian.

Key words: Sweden - Henryk Bukowski - Cracow - books - gifts - Academy of Sciences National Muzeum in Cracow - Jagiellonian Library $-19^{\text {th }}$ century.

Słowa kluczowe: Szwecja - Henryk Bukowski - Kraków - książki - dary - Akademia Umiejętności - Muzeum Narodowe w Krakowie - Biblioteka Jagiellońska - XIX wiek.

Niniejszy artykuł jest wynikiem kwerendy przeprowadzonej w Bibliotece Polskiej w Paryżu we wrześniu 2015 r. dzięki stypendium Towarzystwa Historyczno-Literackiego. W przechowywanym w BPP ogromnym rodzinnym 
Archiwum Gierszyńskich ${ }^{1}$ między innymi dokumentami znajduje się również znaczna ilość materiałów dotyczących znanego bibliofila, antykwariusza, kolekcjonera ze Sztokholmu, członka Rady Muzeum Narodowego Polskiego w Rapperswilu, członka Komitetu Historii Sztuki Akademii Umiejętności (AU) w Krakowie Henryka Bukowskiego (1839-1900).

Cieszący się w środowisku historyków sztuki, badaczy starych druków, historii książki, numizmatów i kolekcjonerów rycin opinią świetnego znawcy swojego fachu właściciel gabinetu-antykwariatu w Sztokholmie, jeden z głównych donatorów Muzeum w Rapperswilu hojnie obdarowywał rozmaite instytucje i biblioteki również w Polsce. Znamienitą część darów stanowiły polonica, gdyż za jedno z najważniejszych zadań swojego życia kolekcjoner uważał zbieranie wszelkich pamiątek polskich i w miarę możliwości przekazywanie ich do kraju albo do Rapperswilu. Godzi się przy tym zaznaczyć, że największa liczba najcenniejszych zdaniem H. Bukowskiego darów trafiła do Krakowa, gdyż, jak to ujął sam ofiarodawca, do innych instytucji w Polsce przekazywał raczej duplikaty lub mniej wartościowe egzemplarze ${ }^{2}$.

Z przykrością trzeba też stwierdzić, że poza krótkimi wzmiankami w sprawozdaniach wspomnianych instytucji, nie została w żaden sposób wyszczególniona zawartość ani objętość otrzymanych od H. Bukowskiego licznych, a w większości przypadków bardzo cennych darów. W niniejszym artykule zostanie podjęta próba przeanalizowania przyczyn ofiarności sztokholmskiego antykwariusza dla poszczególnych instytucji krakowskich oraz zawartości przekazanych do nich darów książkowych.

\section{Droga Polaka z Litwy do Szwecji}

Nie znajdziemy też wielu opracowań poświęconych osobie i działalności Bukowskiego. Po śmierci antykwariusza ukazało się w polskiej i szwedzkiej prasie kilkanaście nekrologów oraz nieliczne, aczkolwiek bardzo wylewne wspomnienia najbliższych współpracowników³ ${ }^{3}$ Na obszerniejsze studium

Emigrant po powstaniu styczniowym, lekarz, działacz polityczny Henryk Gierszyński (1845-1930), wraz z małżonką Marią Kazimierą z Bukowskich Gierszyńską (zm. 1920), synami Stanisławem i Henrykiem oraz córkami Karoliną (Karyllą) i Marią osiedli w Ouarville niedaleko Paryża. Ich dom był otwarty dla wszystkich przybywających z kraju. Gośćmi Gierszyńskich byli m.in. Stanisław Reymont, Stefan Żeromski, Walery Wróblewski. Henryk Bukowski był bratem Marii Gierszyńskiej. Zob. PSB. T. 7: Firlej Jan - Girdwoyń Kazimierz, Warszawa 1948-1958, s. 444445; W. Sladkowski, Wysepka polska we Francji. U Marii i Henryka Gierszyńskich w Ouarville. 1878-1930, Lublin 2005.

2 Zob. BPP, Archiwum Gierszyńskich (AG), akc. 2697, List H. Bukowskiego do W. Łuszczkiewicza z dn. 9 XII 1888 r.

W. Benzelstierna Engeström, Henryk Bukowski (wspomnienie pośmiertne), Poznań 1900; H. Gierszyński, Henryk Bukowski. Wspomnienia pośmiertne z portretem, Paryż 1900; S. Żeromski, Henryk Bukowski, „Tygodnik Ilustrowany” 1900, nr 12, s. 226-227; T. Korzon, Nekrologia. Henryk 
trzeba było czekać wiele lat. Osiadły w Szwecji polski historyk i dziennikarz Michał Haykowski w roku 1990 wydał w Sztokholmie monografię poświęconą osobie Bukowskiego ${ }^{4}$, która niestety nie doczekała się edycji polskiej. Zatem warto w kilku słowach przybliżyć sylwetkę wybitnego zbieracza i donatora poloników.

Urodzony w 1839 r. na Litwie, w majątku Kaukle opodal Poniewieża H. Bukowski nauki szkolne pobierał w Kiejdanach, później Szawlach, aż w końcu udał się na studia do Moskwy. Będąc studentem Wydziału Prawa Uniwersytetu Moskiewskiego brał aktywny udział w działalności liczącej wówczas około 600 osób polskiej społeczności akademickiej. Po powrocie na Litwę jako adiutant księdza Antoniego Mackiewicza uczestniczył w powstaniu styczniowym. Ranny w bitwie pod Popielanami ukrywał się przed policją carską u litewskich chłopów, których darzył wielką sympatią. Dzięki ich pomocy udało mu się dotrzeć do Rygi, skąd, ukrywając się na pokładzie statku, przedostał się do Sztokholmu. Tam po dłuższej tułaczce w roku 1865 został pomocnikiem $\mathrm{w}$ antykwariacie znanego wówczas $\mathrm{w}$ mieście jubilera $\mathrm{i}$ antykwariusza Christiana Hammera (1818-1905)5 , a już w roku 1870 zdołał otworzyć własny sklep z antykami. W środowisku antykwariuszy H. Bukowski znany był jako świetny znawca $\mathrm{W}$ dziedzinie numizmatyki i historii sztuki. Słynął też jako znamienity bibliofil, potrafiący wynajdywać najrzadsze egzemplarze. Zmarł w 1900 r. w Sztokholmie, a pochowany został w Szwajcarii w Rapperswilu.

Mimo rozległych koneksji z najwyższą arystokracją nie tylko Szwecji, ale również Europy ${ }^{6}, \mathrm{H}$. Bukowski był człowiekiem wyjątkowo skromnym, nielubiącym rozgłosu, a przy tym bezgranicznie oddanym swojej ojczyźnie. Stanisław Przybyszewski, który podczas swojego pobytu w Sztokholmie spotykał się z antykwariuszem, opisał go w sposób następujący:

dni swoich dogorywa tam dziwak o niesłychanie gorącym sercu, zdumiewającej ofiarności, fantastycznej miłości ku Polsce, człowiek, który zbyt Polskę i Polaków ukochał, i właśnie wskutek tego stał się zgorzkniałym mizantropem, co sercu jego nie przeszkadzało co chwilę wybuchnąć gorętszym jeszcze płomieniem ukochania: Henryk Bukowski .

\footnotetext{
Bukowski, „Kwartalnik Historyczny” 1900, R. 14, s. 366-374 i inne publikacje.

4 M. Haykowski, Henryk Bukowski. Namnet leverkvar, Stockholm 1990.

5 Także bibliofil, z polecenia króla Karola XV, którego cieszył się zaufaniem, H. Bukowski rozpoczął w jego pracowni swoją karierę jako antykwariusz. Później poślubił siostrę żony swojego chlebodawcy, nie zaprzestając z nim współpracy również po otwarciu własnego antykwariatu i przynajmniej raz w roku jeżdżąc do szwagra, aby pomóc mu w prowadzeniu aukcji, przygotowaniu katalogów oraz wystaw. Zob. Nordisk familijebok, [online] http://runeberg.org/nfbj/0678.html [dostęp 19.10.2018]; S. Żeromski, Listy do Henryka Bukowskiego, oprac. wstęp, koment. W. Wasilewska, Warszawa 1975, s. 369.
}

6 Zob. H. Gierszyński, H. Bukowski..., s. 4.

7 S. Przybyszewski, Moi współcześni, Warszawa 1959, s. 196. 
Znajdziemy wiele świadectw o bezgranicznej miłości i tęsknocie H. Bukowskiego do Polski oraz poświęceniu się sprawom polskim. Piękny jego obraz nakreślił Stefan Żeromski w powieści Ludzie bezdomni ${ }^{8}$. Współcześni H. Bukowskiego również podkreślali jego oddanie sprawom polskim. Sam antykwariusz natomiast niejednokrotnie ubolewał nad jego zdaniem niewystarczająco skutecznymi swoimi wysiłkami na rzecz kraju mówiąc, że: „dobrze odczuwam iż robiąc to, co mi obowiązek względem naszej biednej a drogiej Ojczyzny nakazuje nie zasłużyłem na tak zaszczytne o mnie mniemanie".

Jako jeden z najważniejszych celów swojego życia Bukowski postawił zatem przed sobą niesienie pomocy ukochanej, a utraconej bezpowrotnie Polsce. Pomoc tę pojmował jako wspieranie przede wszystkim instytucji narodowych. Takie nastawienie wyraził w liście do swojej siostry, Marii Gierszyńskiej: „Mię mało obchodzą Czartoryscy, Gałęziowscy i inni, mnie obchodzą instytucje narodowe, na które większą część mej pracy poświęciłem"10.

Antykwariusz zdawał sobie doskonale sprawę, że placówki narodowe czy to w kraju czy poza jego granicami - w szczególnym stopniu potrzebują wsparcia. Był doskonale zorientowany, jakie każda z nich ma cele i zadania, jakie posiada zbiory. H. Bukowski wiedział dokładnie, czym mógłby je wesprzeć, jakie kolekcje można wzbogacić, a które uzupełnić. Koniecznym wydaje się zaznaczyć, że wszystkie instytucje były dla niego tak samo ważne, dlatego traktował je jednakowo, zgodnie z maksymą: „każda instytucja narodowa jest mi miłą"11.

$Z$ relacji współczesnych dowiadujemy się, że w dążeniu do swojego celu nieraz potrafił za polonica zapłacić o wiele wyższą cenę, niż w rzeczywistości były one warte ${ }^{12}$. Cokolwiek mające związek z krajem trafiło w jego ręce, nie szło na sprzedaż, a było przekazywane do Rapperswilu ${ }^{13}$ albo do instytucji i bibliotek w Polsce. W różnych okresach dary od H. Bukowskiego w postaci sztychów, monet, asygnat, obrazów, książek, rękopisów, starodruków, inkunabułów otrzymały między innymi placówki krakowskie: AU, BJ, Muzeum Narodowe, Muzeum Techniczno-Przemysłowe, Muzeum Książąt Czartoryskich $^{14}$ oraz PTPN i wiele innych instytucji i bibliotek w całej Polsce ${ }^{15}$.

8 S. Żeromski, Ludzie bezdomni, T. 1-2, Warszawa 1958.

9 BPP, AG, akc. 2697, List H. Bukowskiego do J. Wdowiszewskiego z dn. 10 X 1895 r.

10 List H. Bukowskiego do M. Gierszyńskiej z dn. 6 XII 1896 r., [w:] W. Stankiewicz, Listy Henryka Bukowskiego do rodziny Gierszyńskich. Źródło do dziejów Muzeum Polskiego w Rapperswilu. [Cz. 1], Warszawa 1971, s. 522.

11 BPP, akc. 434/42, Papiery emigrantów. Litera „B”, List H. Bukowskiego do A. Wołyńskiego z dn. 12 VII 1887 r., k. 759.

12 W. Benzelstierna Engeström, dz.cyt., s. 31.

13 B. Szyndler, Bibliotekarska stużba Stefana Żeromskiego, Wrocław 1977, s. 52-53.

14 „Nowa Reforma”, 1887, nr 1, s. 3.

15 A. Lewak, Bukowski Henryk (1839-1900), [w:] PSB. T. 3: Brożek Jan - Chwalczewski 
Mówiąc o ofiarności H. Bukowskiego nie można nie wspomnieć o tym, że przekazując swoje dary do Muzeum w Rapperswilu lub jakiejkolwiek instytucji w Polsce, nigdy nie domagał się zwrotu kosztów ani zapłaty, a w większości przypadków pragnął pozostawać niezauważalnym: ,Jedyne, co pragnę i co ma dusza potrzebuje to cichego wypoczynku i cichej pracy na niwie ojczystej od nikogo niezależnej" ${ }^{\prime \prime}$. Być może chęć pozostania w cieniu jest jednym z powodów, które utrudniają badaczom poszukiwanie śladów związanych $\mathrm{z}$ darami Bukowskiego.

\section{Ofiarność bezgraniczna}

Wiele przedmiotów, książek i rękopisów H. Bukowski przekazywał różnym instytucjom od samego początku swojej działalności. Przypatrując się dokładniej całej działalności kolekcjonera odnosi się wrażenie, że po to właśnie założył antykwariat, żeby mieć możliwość wyszukiwania pamiątek polskich i po ich nabyciu przekazywania ich do kraju. Wszystko, co się nie mieściło w pojęciu polonica służyło wyłącznie temu, żeby zdobyć fundusze na kolejne ,pamiątki polskie” lub na wsparcie materialne młodzieży polskiej studiującej za granicą ${ }^{17}$. Warto dodać, że antykwariusz czynił to z wielkim zapałem i namawiał innych do „wzmacniania kasy”, mówiąc, że ,jak człek poprze, to idzie samo przez się"18.

Zdaniem wieloletniego dyrektora Biblioteki AU w Krakowie, Władysława Barana, już od 1875 r., czyli kilka lat po otwarciu własnego antykwariatu, najwięcej pamiątek polskich w postaci medali, monet, broni, sprzętów, obrazów, rysunków, sztychów, jak również książek, rękopisów, które udawało się odszukać między innymi w Szwecji, H. Bukowski przekazywał do Muzeum Narodowego Polskiego w Rapperswilu ${ }^{19}$. Antykwariusz ze Sztokholmu uważał, że jest to jedyne właściwe miejsce, gdzie powinny się one znajdować i jako emigrant gorąco popierał istnienie takiej polskiej placówki

Franciszek, Kraków 1937, s. 121; A. Świderska, Bukowski Henryk, [w:] SPKP, Warszawa-Łódź 1972, s. 99-100.

16 BPP, akc. 343/42, Listy emigrantów. Litera „B”, List H. Bukowskiego do A. Wołyńskiego z dn. 31 VII 1889 r., k. 767.

17 H. Bukowski chętnie wspierał materialnie młodzież polską i litewską podejmującą studia na uczelniach europejskich (szczególnie w Szwajcarii oraz Francji); najbardziej znana jest fundowana przez niego „Cicha kasa litewska”, natomiast wiadomo, że wiele jego zdaniem wartościowych działań wspierał finansowo nie podając nazwiska. Zob. Z. Folejewski, Henryk Bukowski, „Svio-Polonica” 1944-1945, nr 6-7, s. 63; Z. Ciesielski, Przypomnienie Henryka Bukowskiego, [w:] Zbliżenia skandynawsko-polskie. Szkice o kontaktach kulturalnych w XIX i XX wieku, Gdańsk 1972, s. 239; A. Lewak, dz. cyt., s. 120.

18 List H. Bukowskiego do M. Gierszyńskiej, z dn. 16 XI 1894 r., [w:] W. Stankiewicz, Listy Henryka Bukowskiego..., s. 499.

19 W. Baran, Henryk Bukowski. Wielki bibliofil polski, Warszawa-Kraków 1926, s. 16. 
poza granicami kraju ${ }^{20}$. Wedle szacunków około dwóch trzecich wszystkich pamiątek polskich Muzeum w Rapperswilu zawdzięczało właśnie ofiarności H. Bukowskiego ${ }^{21}$.

Z upływem czasu coraz więcej darów antykwariusz zaczął przekazywać do różnych instytucji w Polsce, wyraźnie dążąc do tego, aby jak najwięcej pamiątek związanych z krajem wróciło doń z zagranicy i zostało umieszczonych w różnego rodzaju placówkach naukowych, które właśnie zaczynały lub rozwijały swoją działalność.

Trudno jednoznacznie określić, jakimi pobudkami kierował się antykwariusz ze Sztokholmu wybierając Kraków, jako najbardziej odpowiednie miejsce dla przekazywanych przez siebie darów. Możliwe, że zaważyła na tym między innymi ogólna sytuacja Galicji w końcu XIX w., kiedy po przyznaniu jej przez Austrię faktycznej autonomii, Polacy uzyskali znacznie więcej swobód, w wyniku czego zaczęło powstawać więcej rodzimych instytucji naukowych. Między innymi z inicjatywy Adriana Baranieckiego (1828-1891) ${ }^{22}$ zostaje założone Muzeum Techniczno-Przemysłowe w Krakowie, z działającego od 1815 r. Towarzystwa Naukowego Krakowskiego w 1872 r. utworzono Akademię Umiejętności, prawie w tym samym czasie językiem wykładowym na UJ stał się polski, a dosłownie po kilku latach, w roku 1879 uchwałą Rady Miasta założono Muzeum Narodowe w Krakowie. Te wszystkie okoliczności zapewne sprawiają, że Bukowski więcej materiałów przesyła do Krakowa ${ }^{23}$, wkrótce stając się członkiem rozmaitych towarzystw oraz zarządów różnych instytucji krakowskich, między innymi Towarzystwa Archeologicznego, Komisji Historii Sztuki AU i Muzeum Narodowego ${ }^{24}$.

Antykwariusz sztokholmski prowadził obszerną korespondencję z licznymi krakowskimi zbieraczami starożytności, numizmatów oraz książek. Między innymi jednym z najbliższych miejscowych przyjaciół H. Bukowskiego był bibliofil, historyk, kolekcjoner, ksiądz kanonik Ignacy Polkowski

\footnotetext{
20 Tenże, dz. cyt., s. 18.

21 „Sprawozdanie z Zarządu Muzeum Narodowego w Rapperswylu za Rok [1900]” 1901, R. 31, s. 25.

22 Lekarz, założyciel i dyrektor Muzeum Techniczno-Przemysłowego w Krakowie, członek Towarzystwa Muzeum Narodowego Polskiego w Rapperswilu. Zob. I. Bojarska, Adrian Baraniecki (1828-1891), [w:] PSB. T. 1: Abakanowicz Abdank Bruno - Beynart Wojciech, Kraków 1935, s. $270-271$.

23 Warto zaznaczyć, że H. Bukowski zasilał darami nie tylko instytucje, ale również zbiory osób prywatnych. W licznej jego korespondencji z różnymi osobami, często natykamy się na informacje o przesyłanych przez niego markach, sztychach, monetach czy nawet książkach, m.in. do zbiorów bibliotecznych Józefa Ignacego Kraszewskiego, które niejednokrotnie zostały zasilone darami Bukowskiego.

24 J.W. Brzeski, Środowisko Biblioteki Jagiellońskiej w latach 1775-1939. Stownik biograficzny, Kraków 2014, s. 145.
} 
(1833-1888) ${ }^{25}$. Po jego nieoczekiwanej śmierci Bukowski pisał do ówczesnego dyrektora Muzeum Narodowego w Krakowie Władysława Łuszczkiewicza (1828-1900):

Strata to wielka nie tylko dla Krakowa, ale i dla Kraju. Bardzo boleśnie ona mię dotknęła, bo w nim straciłem jednego z najdroższych mi przyjaciół, którego wysoko szanowałem i kochałem jak brata. On to był, co mnie przyciągnął do Krakowa a ileż to jemu każda posyłka sprawiała przyjemności ${ }^{26}$.

Z tej krótkiej notatki można wywnioskować, jak bliskie więzi łączyły H. Bukowskiego z księdzem kanonikiem, z którym poza sprawami kolekcjonerskimi zapewne rozważał również kwestie przekazania swoich zbiorów którejś z krakowskich instytucji ${ }^{27}$. Antykwariusz nie tylko wymienia się z duchownym kolekcjonerem ciekawymi obiektami, ale również z pełnym zaufaniem pożycza mu cenne egzemplarze ${ }^{28}$. Prawdopodobnie nosił się też z zamiarem przekazania wszelkich spraw związanych z Muzeum w Rapperswilu w ręce I. Polkowskiego oraz Tadeusza Romanowicza, redaktora krakowskiej gazety „Nowa Reforma”29.

Dodatkowym impulsem do przekazywania darów nie do Rapperswilu, a do Polski, a szczególnie do Krakowa, była sprawa związana z zamiarem hr. W. Platera powierzenia opieki nad zbiorami w Rapperswilu Akademii Umiejętności w Krakowie. Nie chodziło tu zapewne o samo przekazanie, ani nawet o to, że Zarząd Akademii wówczas odmówił, argumentując, że zbiory te nie mają żadnej wartości. O wiele większe niezadowolenie, a nawet gniew H. Bukowskiego wzbudziło nieudolne zarządzanie W. Platera zbiorami Muzeum Narodowego. Wyraźnie to napisał w liście do historyka, organizatora Muzeum Mikołaja Kopernika w Rzymie, Artura Wołyńskiego ${ }^{30}$ :

25 R. Bender, Ignacy Polkowski (1833-1888), [w:] PSB. T. 27: Pniowski Jan-Potocki Ignacy, Wrocław 1983, s. 322-324.

26 BPP, AG, akc. 2697, List H. Bukowskiego do W. Łuszczkiewicza z dn. 15 IX 1888 r.

27 Tamże, List H. Bukowskiego do W. Łuszczkiewicza z dn. 20 VIII 1888 r.

28 Między innymi Regum Polonicae Icones, Per Tho. Treterum Polonum, Roma 1591, o czym wspomina w liście do W. Łuszczkiewicza z dn. 13 V 1888 r., zob. BPP, AG, akc. 2697: „On mię usilnie prosił aby mu odstąpić ale nie mogłem, więc nacieszywszy się miał wam odesłać. Dzieło to niepodobne do znalezienia więc trzeba go koniecznie wydostać dla Muzeum, o którym nie zapominam". Prawdopodobnie jednak nie udało się odzyskać egzemplarza, gdyż w Bibliografii polskiej K. Estreichera przy wymienionym egzemplarzu widnieje następująca adnotacja: ,Jest to zapewne ten sam egzemplarz, który był niegdyś własnością ks. Ign. Polkowskiego, a który po jego śmierci nabył Aleksander Poniński z Horyńca" - K. Estreicher, Bibliografia polska. Cz. 3, t. 20, Kraków 1936, s. 313. Zob. też K. Mroziewicz, "Regum Poloniae Icones» Tomasza Tretera ze zbiorów Biblioteki Królewskiej w Sztokholmie i szwedzkie watki w listach serii, „Folia Historiae Artium. Seria Nowa" 2017, s. 25-34.

29 BPP, AG, akc. 2697, List H. Bukowskiego do W. Łuszczkiewicza z dn. 13 V 1889 r.

30 Biogram Artura Wołyńskiego (1844-1893), w: SPKP, Warszawa 1972, s. 984-985. 
Do Platera mam silną urazę, że mych rad nie słuchał i zwichnął w samym kwiecie rozwój Muz. Nar. a zmusił mnie opuścić Rapper. i przenieść moją pracę do Krakowa. Nie żałuję tego, bo każda instytucja narodowa jest mi miłą, ale dla każdego zbieracza jest miło mieć owoce swej pracy pod jedną strzechą. Całe jego działanie świadczy, że był upartym durniem a resztę wykażą jego papiery - zawczasu żadne [sądy - G.L.] wydawać nie mam prawa ${ }^{31}$.

Widocznie całkowity brak odpowiedzialności w działaniach W. Platera dotyczących spraw Muzeum oraz jakiejkolwiek wizji rozwoju tej instytucji zaważyły na decyzji H. Bukowskiego o przekazaniu znacznej części swoich zbiorów do Krakowa, o czym informował swoją siostrę M. Gierszyńską:

Upór Platera i niesumienne postępowanie z młodzieżą osłabiły mój zapał dla Muz. Nar. w Rapperswilu a więc i bez tego me uczucia powoli przeszły do Krakowa dałem dowód im składając Zygmunta Augusta arcydzieło. Dziś jestem skrępowanym i to niemiło ${ }^{32}$.

Być może Bukowski otrzymał od władz krakowskich propozycję objęcia opieki nad jakąś placówką, lub przeniesienia swojej działalności do Krakowa. Aczkolwiek nie udało się znaleźć źródła potwierdzającego takie przypuszczenie, jednak podobny wniosek można wysnuć z treści cytowanego niżej listu:

Z wysokiego i niezasłużonego zaszczytu Bóg świadkiem nie jestem rad, bo nie posiadam głębokiej nauki - na moskiewskich ławach nie tak łatwo jest zdobyć 1863 przerwał studia a tu na wygnaniu wśród antyków człek głupieje i staje się maszyną, - ale pojmuję oni pragną mnie przyciągnąć do Krakowa pragną mej pracy zużytkować a to i bez tego zaszczytu z niekłamaną i wrodzoną przyjemnością uczynię jak czyniłem dotąd $\mathrm{d}^{33}$.

Zapewne nie bez znaczenia dla decyzji o przekazaniu części swoich zbiorów do polskich instytucji była obawa, że po jego śmierci wszystko może przepaść: „człek śmiertelny piątą kreskę kończę a więc zanim przejdę do wieczności pragnę moje dary i opiekę nad niemi powiększyć w pewne ręce"34.

Z korespondencji H. Bukowskiego do siostry, W. Łuszczkiewicza i do innych osób wynika, że nie od razu podjął decyzję, jakiej placówce pragnąłby przekazać swoje zbiory.

\section{Muzeum Narodowe w Krakowie}

Najstarsza placówka tego typu w Polsce została powołana w 1879 r. w Krakowie z inicjatywy Józefa Dietla (1804-1878), pierwszego prezydenta miasta. Dyrektorem Muzeum decyzją Rady Miasta został wybrany w 1883 r. malarz, historyk sztuki, konserwator W. Łuszczkiewicz. Głównym zadaniem nowo powołanej instytucji było gromadzenie i upowszechnianie sztuki polskiej. k. 761 .

BPP, AG, akc. 434/42, List H. Bukowskiego do A. Wołyńskiego z dn. 12 VII 1887 r.,

32 Tamże, akc. 2697, List H. Bukowskiego do M. Gierszyńskiej z dn. 7 VII 1887 r.

33 Tamże.

34 BPP, AG, akc. 2697, List H. Bukowskiego do W. Łuszczkiewicza z dn. 13 V 1888 r. 
Nie trzeba było długo czekać, aż sztokholmski antykwariusz nawiąże kontakt z dyrektorem Muzeum i zacznie przekazywać doń dary. Już w $1884 \mathrm{r}$. W. Łuszczkiewicz pisze do H. Bukowskiego list z podziękowaniem za nadesłane ze Sztokholmu obiekty ${ }^{35}$. Po przeanalizowaniu przechowywanej w Archiwum Gierszyńskich w BPP korespondencji, a właściwie listów z podziękowaniami dla $\mathrm{H}$. Bukowskiego za ofiarowane przedmioty i książki, można wywnioskować, że współpraca ta trwała z krótkimi przerwami co najmniej do roku 1891. Z tej korespondencji dowiadujemy się też, że pierwotnym zamiarem antykwariusza ze Sztokholmu było przekazanie większej części posiadanych zbiorów właśnie do Muzeum Narodowego w Krakowie. Zamiar ten nie został urzeczywistniony, gdyż uwzględniwszy specyfikę zbiorów Muzeum, oraz po konsultacjach z krakowskim środowiskiem naukowym H. Bukowski ostatecznie zmienił zdanie i postanowił przekazać tej instytucji głównie kolekcje monet, medali, asygnat, sztychów oraz dzieła sztuki związane z Polską. Godzi się zaznaczyć, że antykwariusz nie tylko był doskonale zorientowany, jaki jest profil zbiorów danej placówki, ale również dzielił się sugestiami odnośnie uzupełnienia jej kolekcji:

załączyłem kilka dzieł, w których są karty tytułowe wykonane przez Falcka ${ }^{36}$ lub inne portrety polskie do Muzeum Narodowego - Według mego zapatrywania podobne dzieła powinny wchodzić w zakres zbiorów Muzeum Narodowego ${ }^{37}$.

Mając na uwadze to, że priorytetowym zadaniem władz Muzeum było pozyskiwanie do swoich zbiorów eksponatów, a nie wydawnictw, nie dziwi fakt, że H. Bukowski ofiarował mu tylko nieliczne książki ${ }^{38}$. Cenną pomocą w poszukiwaniu darów antykwariusza dla tej placówki okazał się przechowywany w Archiwum Muzeum Narodowego „Inwentarz Władysława Łuszczkiewicza" (z lat 1884-1892), w którym dyrektor własnoręcznie notował wszystkie nabytki. Zapisy są szczegółowe, poza numerem porządkowym, dokładnym opisem proweniencji nabytku jest również numer inwentarzowy, a wiele z nich zostało opatrzonych dodatkowymi uwagami. Warto też wspomnieć, że przy niektórych przedmiotach ofiarowanych Muzeum przez H. Bukowskiego widnieje adnotacja: „Pominięto jako bez wartości dla tutejszego muzeum”39.

35 BPP, AG, akc. 2699, Pismo z dn. 30 XI 1884 r. Komitetu Muzeum Narodowego w Krakowie do H. Bukowskiego z podziękowaniem za przekazane dary.

36 Jeremiasz Falck (1609-1677) uważany za najznakomitszego rytownika swojego czasu, autor ponad 500 sztychów; wykonywał portrety znanych osobistości z epoki, karty tytułowe oraz ryciny do książek.

37 Archiwum Muzeum Narodowego w Krakowie (AMNK), sygn. 94/13, List H. Bukowskiego do W. Łuszczkiewicza z dn. 7 XI 1887 r., k. 67.

38 W inwentarzach W. Łuszczkiewicza przechowywanych w AMNK można znaleźć wiele wpisów na temat przekazanych przez H. Bukowskiego całych kolekcjach monet, asygnat; ofiarował on też prawie pełny komplet sztychów J. Falcka, wiele portretów oraz innych pamiątek polskich.

39 Zob. AMNK, sygn. 94-10, Inwentarz Władysława Łuszczkiewicza z r. 1885. 
W ten sposób zakwalifikowane zostały również katalogi wydawane przez antykwariusza ${ }^{40}$. Mimo to komisja muzealna wystosowała do ofiarodawcy listy dziękczynne za przekazanie między innymi „,pięciu Katalogów szwedzkich z Jego zbiorów monet, obrazów, książek itp. z lat 871-885”, „kilku ksiąg obrazkowych”, „ciekawej augsburskiej książeczki ilustrowanej”41.

Poza wspomnianym „Inwentarzem” W. Łuszczkiewicza o szwedzkim donatorze dla Muzeum dowiadujemy się jedynie z publikowanych „Sprawozdań Zarządu..." Muzeum Narodowego ${ }^{42}$. Wymienia się w nich nazwisko Polaka pośród innych ofiarodawców. Niestety, nie udało się na ich podstawie bliżej ustalić, jakie konkretnie druki czy książki przekazał Bukowski. Takie informacje nie zostały też wyszczególnione w żadnym innym źródle. Pozostaje tylko mieć nadzieję, że książki nie zostały oznaczone jako bezwartościowe i trafiły do biblioteki Muzeum.

Mimo braku wiadomości o poszczególnych darach $\mathrm{H}$. Bukowskiego dla Muzeum Narodowego w Krakowie trudno nie zwrócić uwagi na wylewność jego dyrektora, wyrażającego w listach wdzięczność antykwariuszowi za jego ofiarność i poświęcenie dla Polski:

Już nie mam słów do wyrażenia mojej wdzięczności dla tak Wielkiego Dobrodzieja Muzeum, ale niech Bóg zapłaci miłemu Panu za tę miłość Ojczyzny, za tę gotowość do ofiar dla niej - niech Ojczyzna zanotuje imię Pańskie jako dobrego sługi, który w jakimkolwiek znajdzie się położeniu umie Jej służyć, a służyć dobrze ${ }^{43}$.

\section{Biblioteka Jagiellońska}

Trudno dokładnie powiedzieć, kiedy i w jakich okolicznościach zaczęła się współpraca $\mathrm{H}$. Bukowskiego z BJ. Incydentalne dary książkowe do Biblioteki, podobnie jak do innych placówek w Polsce, antykwariusz przekazywał prawdopodobnie od początku swojej działalności. Chociaż żadne źródła nie potwierdzają takiego faktu, to znając ofiarność antykwariusza wobec innych instytucji krajowych, możemy przyjąć, że nie ominął on również i tej krakowskiej książnicy. Być może dary te z nieznanych obecnie przyczyn zostały pominięte w księgach akcesyjnych BJ, warto jednak pamiętać, że sztokholmski antykwariusz w tym okresie swojej działalności najwięcej uwagi poświęcał Muzeum Narodowemu w Rapperswilu i właśnie tam kierował większość najcenniejszych jego zdaniem eksponatów, druków

\footnotetext{
40 H. Bukowski regularnie wydawał katalogi swoich aukcji. Ukazało się ich około 140. Wiele tych publikacji przekazał również bibliotekom w Polsce.

41 BPP, AG, akc. 2699, Podziękowanie od Komitetu Muzeum Narodowego w Krakowie dla H. Bukowskiego za przekazane dary.

42 „Sprawozdanie Zarządu Muzeum Narodowego za Rok 1889” 1890, s. 6, 9, 11, 22, 23.

43 BPP, AG, akc. 2699, List W. Łuszczkiewicza do H. Bukowskiego z dn. 9 V 1891 r.
} 
oraz rękopisów. Do Polski przesyłał wówczas głównie dublety lub mniej wartościowe egzemplarze.

W księgach akcesyjnych BJ pierwszy znaczący dar H. Bukowskiego został odnotowany w roku 1885 . Wtedy, według zapisu, antykwariusz przysłał ze Szwecji cztery dzieła wydane w Sztokholmie: rozprawę o detronizacji króla Zygmunta III Wazy i jego potomków Exegesis Historica, Non Minvs Aeqvas, Qvam Graves Commemorans Cavsas, Qvibus Amplissimi Ordines Regni Sueciae... z 1620 r. autorstwa szwedzkiego dyplomaty Nicolausa Chesnecopherusa; tomik wierszy w języku szwedzkim Tider och Tilfällen författade Poetiska Dikter Af henne sielf å Nyo öfversedde, samt med dertil hörige kopparstycken förökte szwedzkiej poetki Sophie Elisabeth Brenner z 1713 r.; faksymile pierwszej książki wydrukowanej w Szwecji (1483 r.) w języku łacińskim Dyalogus creaturarum optime moralizatus... Nicolausa Pergamenusa wydane w 1883 r. oraz Acta et literae ab VIII Maji a. 1624 ... inter utriusque Regni Sueciae et Poloniae Senatores ac officialis commutatae ex mandato S. R. M. Sueciae z 1625 r. Poza tym w darze znajdowało się jeszcze pięć broszur. Warto zaznaczyć, że przesyłka ta nie została odnotowana przez Karola Estreichera w Kronice Biblioteki Uniwersytetu Jagiellońskiego... (Kraków 2012).

W następnym, 1886 r., w księgach akcesyjnych Biblioteki nie pojawiła się ani jedna notatka o H. Bukowskim, z czego można wnosić, że albo nie przekazał książnicy żadnych dzieł, albo nie miały one takiej wartości, by je opisać, lub też ewentualne dary po prostu zostały pominięte przez niedopatrzenie, co nie było rzadkością.

Natomiast w roku $1887 \mathrm{H}$. Bukowski przekazał BJ prawdopodobnie największy dar. Składał się on z aż 30 dzieł w 42 tomach, 336 broszur szwedzkich na temat historii Polski, jednego rękopisu oraz czterech map ${ }^{44}$. Między innymi dziełami była tam druga edycja traktatu Mikołaja Kopernika De Revolvtionibus orbium coelestium, Libri VI..., która ukazała się w 1566 r. w Bazylei. Na karcie katalogowej tego dzieła znajdującej się w „Katalogu Podstawowym" BJ (sporządzonym przed 1949 r.) wpisano następującą adnotację: „1887.a.513. Drugi egzemplarz w zbiorze H. Bukowskiego darowany w r. 1887".

W darze z 1887 r. znajdowała się znaczna liczba dzieł dotyczących historii Polski oraz stosunków między Polską a Szwecją. Należały do nich: Konung Sigismund Och Konung Carl den IX, des Historier... szwedzkiego poety, tłumacza i dyplomaty Jonasa Werwinga, wydanie sztokholmskie z 1746 r.;

44 K. Estreicher, Kronika Biblioteki Uniwersytetu Jagiellońskiego od 1811 roku, opr. i wstęp J. Brzeski, Kraków 2012, s. 129; W. Berbelicki, Dary dla Biblioteki Jagiellońskiej w latach 18681904, Kraków 1959, s. 73. 
parysko-warszawska, dwutomowa edycja z roku 1761 dzieła Gabriela Franciszka Coyera Histoire de Jean Sobieski, roi de Pologne. Należy jeszcze wspomnieć o innym druku ofiarowanym przez H. Bukowskiego: Mandata ... Sigismvndi, Sveciae Et Poloniae ... Regis Nec Non ... Ad ... Principem ... Carolvm... (Sztokholm 1596).

Oprócz dzieł oryginalnych H. Bukowski przekazał Bibliotece przekłady tekstów autorów polskich. Pośród nich wymienić należałoby dwukrotnie wydaną w Sztokholmie $(1835,1836)$ pracę oficera napoleońskiego i emigranta Romana Sołtyka ${ }^{45}$ poświęconą politycznej i militarnej historii Polski: Polen, historisk, politisk och militarisk skildring af dess revolution och frihetskrig 1830 och $31 \ldots{ }^{46}$ Znalazły się w tym darze także aż trzy utwory autora powieści historycznych Aleksandra Bronikowskiego ${ }^{47}$, przetłumaczone na język szwedzki. Były to: Polens historia wydana w Christianstadt w roku 1832; dwutomowa powieść historyczna Johan Kasimir Vasa, eller Franska fångenskapen..., która ukazała się w Sztokholmie w tymże roku; wydany w 1834 r. w Kopenhadze przekład na język szwedzki Magyarerne. Første Afdeling: Trolovelsesfesten i Murany - jednej z nielicznych powieści tego autora, które nie doczekały się edycji w języku polskim.

Poza dziełami historycznymi na omawianej liście darów znajduje się również literatura piękna oraz przygodowa, jak na przykład pamiętniki hr. Maurycego Beniowskiego (1746-1786) - wydanie paryskie z 1791 r. Voyages Et Mémoires... oraz ich przekład Samuela Ödmanna na język szwedzki z tego samego roku ${ }^{48}$. W tej kategorii mieści się również przesłane przez H. Bukowskiego w 1888 r. szwedzkie thumaczenie powieści Józefa Ignacego Kraszewskiego Hrabina Cosel $^{49}$ z wyraźną odręczną adnotacją na egzemplarzu: „Od H. Bukowskiego. 1888.a.1311”. Trzeba jednak przyznać, że tego rodzaju literatura stanowiła nieznaczną część darów antykwariusza sztokholmskiego dla BJ.

Kolejna przesyłka od H. Bukowskiego dotarła do krakowskiej książnicy w następnym, 1888 r. Zawierała druki ,szwedzko-polskie” w liczbie 21 dzieł

\footnotetext{
45 W. Zajewski, Roman Soltyk (1790-1843), [w:] PSB. T. 40: Soczyński Karol - Sowiński Ignacy, Warszawa-Kraków 2000-2001, s. 420-423.

46 Oryginał La Pologne. Précis historique, politique et militaire de sa révolution, précédé d'une esquisse de l'histoire de la Pologne depuis son origine jusqu'en 1830... T. 1-2, Paris 1833, przyniósł autorowi europejski rozgłos i doczekał się przekładów na język niemiecki, włoski oraz dwukrotnie szwedzki (1834-1835), zob. W. Zajewski, dz. cyt.

47 H. Więckowska, Ksawery Bronikowski (1783-1834), [w:] PSB. T. 2: Beyzym Jan - Brownsford Maria, Kraków 1936, s. 468-470.

48 M.A. Beniowski, Lefnadslopp och Resor, af honom sielf beskrefne, Stockholm 1791.

49 J.I. Kraszewski, August den starke och grefvinnan Cosel ..., på svenska utgifven af C. Eichhorn, Stockholm 1881.
} 
i 138 broszur $^{50}$. Antykwariusz przekazał Bibliotece między innymi Katalog rzadkich druków polskich ze zbiorów Henryka Bukowskiego, który został wydany w 1887 r. w Sztokholmie ${ }^{51}$. Wydaje się stosownym poświęcić nieco więcej uwagi tej publikacji, która zawiera 405 pozycji. Katalog podzielony został na dwa osobne działy. Pierwszemu z nich nadano tytuł Polonica. Skrifter i olika amnen (Pisma i rzeczy różne). Zawiera on 138 pozycji ułożonych w porządku alfabetycznym. Znajdują się tutaj dzieła różnych autorów, zarówno polskich, jak i zagranicznych - wydane po łacinie, szwedzku, francusku i tylko nieliczne w języku polskim. Są to polonica opublikowane w różnych miastach Europy, najczęściej w Warszawie, Krakowie, Wilnie, Antwerpii, Amsterdamie, Paryżu, Rydze, Sztokholmie, Poznaniu.

Drugą część Katalogu (pozycje 139-403), jak sugeruje jej tytuł Kriegsrelationer, fredstraktater etc. (Relacje wojenne, traktaty pokojowe etc.), stanowiły różnego rodzaju druki, ale też rękopisy, akty i inne dokumenty w różnych językach związane z historią Polski. Na marginesach znajdują się imiona władców (np. „Sigismunti III”, „Vladislaus VI”), pełniąc funkcję rozdziału wyznaczającego, do której postaci odnoszą się wyszczególnione pozycje. Warto nadmienić, że przy niektórych dziełach zawartych w omawianej części Katalogu zostały dodane małe literki „r”. Można przypuszczać, że oznaczały stopień rzadkości danego druku - czasem występuje jedna, dwie lub aż trzy takie literki.

Ostatnie dwie pozycje Katalogu (pod numerami 404 i 405) stanowią katalogi przygotowane przez szwedzkiego bibliofila, wydawcę, autora bibliografii starodruków szwedzkich, Gustawa Edwarda Klemminga (1823-1893).

Omawiany Katalog został wydany tylko w 22 egzemplarzach. H. Bukowski rozesłał go do różnych instytucji oraz bibliotek w Polsce. Być może, że wyodrębniając polonica $\mathrm{z}$ ogólnego zbioru antykwariusz miał zamiar zasugerować nabycie przynajmniej części z nich przez klientów z kraju. Niestety, nie ma żadnego potwierdzenia tego przypuszczenia, ani też nie wiadomo, czy oferta antykwariusza miała jakikolwiek odzew. Nie ulega jednak wątpliwości, że duża część wyszczególnionych w Katalogu dzieł w różnych okresach trafiła jako dary do BJ. Taki wniosek nasuwa się po porównaniu zawartości Katalogu z księgami akcesyjnymi Biblioteki ${ }^{52}$.

W 1891 r., jak podaje Kronika Biblioteki Jagiellońskiej... K. Estreiche$\mathrm{ra}^{53}$, krakowska książnica otrzymała od $\mathrm{H}$. Bukowskiego tylko jedno dzieło.

$50 \quad$ W. Berbelicki, dz. cyt., s. 73.

51 [H. Bukowski], Katalog rzadkich druków polskich ze zbiorów H.B. w Sztokholmie. Oddruk z katalogu ogólnego od Nr 1501 do 1895, w 22 egzemplarzach, Stockholm 1887.

${ }_{52}$ Zob. BJ, Księgi akcesyjne Biblioteki Jagiellońskiej, lata 1884-1899, rps, karty nienumerowane.

53 K. Estreicher, Kronika..., s. 141. 
Rzeczywiście, w księdze akcesyjnej pod numerem 103 została wpisana 16-tomowa bibliografia druków i manuskryptów szwedzkich Bibliotheca Historica Sveo-Gothica... (Sztokholm 1791) ${ }^{54}$ autorstwa szwedzkiego historyka, bibliofila Carla Gustawa Warmholtza (1713-1785).

Według Władysława Berbelickiego dopiero po ośmiu latach (w 1899 r.) H. Bukowski przekazał BJ kolejny dar. Autor tej informacji nie podał jednak ani wielkości ani zawartości przesyłki. Nie wyróżnił nawet nazwiska donatora thustym drukiem ${ }^{55}$, co zgodnie z przedmową do książki Berbelickiego oznacza, że dar antykwariusza nie był wyjątkowy ani pod względem ilości przekazanych materiałów, ani ich wartości. Rzeczywiście, było to tylko 11 broszur oraz katalogi aukcji o numerach 107-118 i 120-123.

Nie zmienia to ogólnej oceny wartości darów H. Bukowskiego dla krakowskiej książnicy. Wystarczy wspomnieć, że w Katalogu poloników XVI wieku Biblioteki Jagiellońskiej (Kraków 1992-1995) zostały zarejestrowane aż 22 druki ofiarowane przez H. Bukowskiego ${ }^{56}$, w tym Copey Eines Schreibens Welchs in Lateinischer sprachen, der Herr Stanislaus von Zarnkow ... vnd der Herr Johan Zamoiski ... An Hertzog Carln zu Schweden ... Bey dem Herrn Samuel Lasky, Königlichen Gesandten abgehen lassen. Und Was ... Hertzog Carl ... darauff geantwortet, wydana w Uppsali w 1598 r. Znajdziemy tutaj też dzieło polskiego kalwina i filozofa prawa Andrzeja Wolana (1530-1610) Oratio Ad Illvstres Radivillos et Chotkiewicios..., wydane w drukarni Ulryka i Salomona Sultzerów w Wilnie w roku 1600. Antykwariusz podarował Bibliotece również dwa wydania kroniki Balthasara Russowa (1536-1600): Chronica Der Prouintz Lyfflandt ... oraz pod tytułem Nye Lyfflendische Chronica... - obie edycje ukazały się w 1578 r. w Rostoku.

Po sprawdzeniu roku akcesji na kartach katalogowych w „Katalogu Podstawowym" BJ okazało się, że niemal wszystkie z wymienionych pozycji zostały przekazane książnicy w roku 1887. Trzeba jednak zaznaczyć, że tylko nieliczne $\mathrm{z}$ nich zostały odnotowane $\mathrm{w}$ księgach akcesyjnych ${ }^{57} . \mathrm{Z}$ tego można wywnioskować, że w roku 1887, a przypuszczalnie i w innych latach H. Bukowski ofiarował BJ znacznie więcej darów, niż to zostało odnotowane zarówno w księgach akcesyjnych, w Kronice jak i w innych dokumentach książnicy.

Niektórych dokumentów rękopiśmiennych H. Bukowski tylko użyczał Bibliotece, w celu sporządzenia z nich kopii. Jednym z nich był na przykład

\footnotetext{
54 BJ, Księga akcesyjna Biblioteki Jagiellońskiej z 1891 r., rps, karty nienumerowane.

55 W. Berbelicki, dz. cyt. s. 78.

56 Katalog poloników XVI wieku Biblioteki Jagiellońskiej. T. 1: A- , pod red. M. Malickiego, E. Zwinogrodzkiej, Kraków 1992, s. 35-36 i in.

57 Sprawdzanie pozycji w księgach akcesyjnych nie jest w pełni miarodajne, gdyż często tytuły dzieł są zapisane bardzo skrótowo, dlatego nieraz są trudne do odczytania i zidentyfikowania.
} 
Diariusz z 1635 r. dotyczacy rokowań polsko-rosyjskich. Dokument ten został w całości przepisany, a do kopii dołączono kartkę z następującym dopiskiem ręką K. Estreichera: „Manuskrypt własność biblioteki Stokloster w Szwecji przysłany przez H. Bukowskiego ze Sztokholmu do przepisania. O nim Tyszkiewicz w Podróży po Szwecji T. I, s. 156-157'. Nie jest pewne, dokąd kolekcjoner przekazywał oryginały, być może trafiały do Rapperswilu.

Badając dary H. Bukowskiego dla BJ nasuwa się pytanie o przyczyny tak nielicznych podarunków książkowych antykwariusza dla tej książnicy, wówczas bardzo prężnie rozwijającej się pod kierownictwem K. Estreichera. Wiadomo, że w celu pozyskania druków dla najważniejszej biblioteki kraju, która w myśl jej dyrektora miała zostać książnicą narodową, K. Estreicher wykorzystywał wszelkie możliwości, w tym kontakty osobiste. Mimo to, nie udało się dotychczas natknąć na jakikolwiek ślad korespondencji między H. Bukowskim a K. Estreicherem. Możliwe, że nie zachowała się, albo nie została jeszcze odnaleziona, jednak wiele wskazuje na to, że jej po prostu nie było. Być może na ich stosunkach osobistych zaważyła sprawa Rapperswilu ${ }^{58}$. Wiadomo, że K. Estreicher nigdy nie krył swojego negatywnego nastawienia wobec Muzeum Narodowego Polskiego w Szwajcarii, jako placówki emigracyjnej. Uważał bowiem, że taka instytucja powinna powstać w kraju, nawet, jeżeli jej zbiory będą narażone na zabór i wywiezienie ${ }^{59}$. Postawa dyrektora BJ znanego z ostrych i bardzo bezpośrednich sądów była swojego rodzaju obrazą dla osób skupionych wokół Rapperswilu. Emigranci byli przekonani, że będąc na obczyźnie - niekoniecznie $\mathrm{z}$ własnego wyboru - mają patriotyczny obowiązek gromadzić wszystko, co może mieć jakikolwiek związek z utraconą „,biedną Ojczyzną”. Dlatego wypowiedzi K. Estreichera o tym, że „emigracja zbiorów polskich jest wysysaniem ostatnich zasobów umysłowych z kraju” i ,rola Rapp. skończyła się ze śmiercią Platera" ${ }^{" 00}$ musiały być bolesne również dla H. Bukowskiego. Możliwe też, że mogły zniechęcić antykwariusza do przekazywania darów BJ. Wolał ofiarować je innych innym krakowskim instytucjom, na przykład Muzeum Narodowemu lub Akademii Umiejętności.

58 W. Plater nie mogąc samodzielnie podołać zarządzaniu coraz większymi zbiorami, ani też zajmować się rekonstrukcją zamku (co było jednym z warunków dzierżawy Rapperswilu), postanowił w roku 1873 przekazać placówkę pod opiekę powstającej w tym czasie Akademii Umiejętności w Krakowie. Jednak ówczesny sekretarz generalny Józef Szujski uznał, że zbiory te nie mają żadnej wartości dla naukowej działalności Akademii i odmówił przyjęcia daru. W polemikę podjętą w prasie krakowskiej nad zasadnością zamiarów W. Platera włączył się również K. Estreicher bardzo negatywnie oceniając utrzymanie i potrzebę takich zbiorów na emigracji.

59 K. Estreicher, O Rapperswylu. Głos drugi i ostatni, Kraków 1883, s. 19.

60 J. Hulewicz, Związki Estreichera z Akademia Umiejętności, [w:] Księga pamiątkowa ku czci Karola Estreichera (1827-1908). Studia i rozprawy, Kraków 1964, s. 316. 


\section{Akademia Umiejętności w Krakowie}

Biblioteka Akademii otrzymała od H. Bukowskiego jeden z większych darów książkowych. Nastapiło to w roku 1889, aczkolwiek współpraca antykwariusza sztokholmskiego z AU rozpoczęła się znacznie wcześniej. W sierpniu 1884 r. ówczesny sekretarz generalny Stanisław Tarnowski wysłał do H. Bukowskiego poświadczenie otrzymania daru w postaci jednego dzieła przekazanego do zbiorów Akademii ${ }^{61}$. Nie wiadomo, czy wcześniej antykwariusz ofiarował cokolwiek ze swoich zbiorów krakowskiej placówce naukowej - nie ma na to żadnych dowodów, ani podziękowań, ani też wpisów do ksiąg. Nie ma takich poświadczeń aż do roku 1888. Można jedynie przypuszczać, że H. Bukowski przysyłał już wcześniej dary ze Sztokholmu. Ponieważ jednak w Bibliotece nie prowadzono systematycznie zapisów przybytków i darów ${ }^{62}$, nie zostały one udokumentowane.

Mimo to, śmiało można postawić hipotezę, że H. Bukowski mógł mieć plan przekazania większego daru właśnie Bibliotece AU. Uzasadnia ją list antykwariusza do ówczesnego dyrektora krakowskiego Muzeum Narodowego W. Łuszczkiewicza:

od Dr. Bylickiego ${ }^{63}$ dowiedziałem się, że Akad Umiejętności posiada własną Bibliotekę. Gdym wysyłał me drobne druki szwedzkie dotyczące dziejów naszej Ojczyzny, pragnąłem oddać Akad. Umiej. Ale o ile przypominam sobie P. Polkowski mi radził oddać Akad. Jagiel. ect. ect. Może będzie najlepiej oddać zbiór Akad. Um. tj. a raczej Komisji Sztuki i pozostawić do jej decyzji ${ }^{64}$.

Przypuszczalnie księgarz już wcześniej prosił dyrektora Muzeum o radę w tej sprawie, gdyż w liście do niego pisał: „teraz wracam do łaskawie podanego projektu" ${ }^{65}$. Można zatem przypuszczać, że pomysł przekazania darów do Krakowa był rezultatem dłuższych rozważań. W cytowanym liście H. Bukowski pisał też, że:

Oprócz tego (ale to pod zastrzeżeniem największej dyskrecji) posiadam własną podręczną bibliotekę dotycząca głównie mego fachu. Ten zbiór jeśli nie za życia to po śmierci odbiera Akad. w Krakowie ${ }^{66}$.

Pretekst do przyspieszenia decyzji nadarzył się niebawem, o czym antykwariusz pisał do prezesa AU Józefa Mayera:

61 BPP, AG, akc. 2699, Zarząd Akademii Umiejętności w Krakowie, 8 VIII 1884 r.

62 E.H. Nieciowa, Stanisław Windakiewicz jako bibliotekarz, „Rocznik Biblioteki Polskiej Akademii Nauk w Krakowie" 1968, R. 14, s. 134

63 W. Ziembicki, Władysław Bylicki (1846-1931), [w:] PSB. T. 3, s. 170. Znajomość Bukowskiego $\mathrm{z}$ doktorem przypuszczalnie nawiązana została poprzez Władysława Harajewicza, zięcia H. Bukowskiego, który podobnie jak W. Bylicki był lekarzem w szpitalu Św. Łazarza w Krakowie.

${ }^{64}$ BPP, AG, akc. 2697, List H. Bukowskiego do W. Łuszczkiewicza z dn.13 V 1888 r.

65 Tamże.

66 Tamże. 
Dzięki Najwyższemu ćwierć wieku mija jakem zmuszony opuścić drogą Ojczyznę osiadł tu na wygnaniu a zarazem upływa pół wieku mego życia. Dla uczczenia tej chwili, której nigdy nie miałem nadziei dożyć postanowiłem za życia to uczynić, co pięć lat temu moim testamentem wyraziłem. To mnie zniewala prosić i utrudniać J. W. Pana Prezesa aby raczył być thumaczem mej myśli i prośby do Akad. Umiej. w Krakowie ${ }^{67}$.

W dalszej części listu dodawał, że:

Paki złożone pod Waszą strzechą przez wielce Szanownego Dyr. Łuszczkiewicza zawierają większą część mej podręcznej biblioteki. Są to owoce mej pracy, moja gleba, którą orałem na wygnaniu a ta praca dzięki Bogu wydała pomyślne plony, składam je w ofierze drogiej Ojczyźnie z prośbą aby Akad Umiejętności przyjęła dla swego użytku ${ }^{68}$.

Jako człowiek skromny i nielubiący rozgłosu, posyłając dar do Krakowa antykwariusz wyraźnie zastrzegał, że nie życzy sobie, aby jeszcze za życia jego imię było wymieniane w sprawozdaniu czy w dziennikach AU:

zechciej użyć n.p. «Od jednego z członków lub przyjaciela sztuki Ak. Um. odebrała w darze ect.». Pojmie dobrze każdy członek i moi znajomi pojmą od kogo byle nie szersza publiczność o tem wiedziała ${ }^{69}$.

Nie chciał też zgodzić się, żeby ofiarowany zbiór nosił jego imię, uzasadniając swoje postanowienie tym, że każda z jego książek jest opatrzona ekslibrisem $^{70}$, więc badacze z łatwością się domyślą, skąd pochodzi i kto jest jej darczyńcą. Godzi się zaznaczyć, że większość dzieł z przekazanego zbioru miała bogato zdobioną oprawę introligatorską, co niewątpliwie podnosiło wartość daru.

Zgodnie z wolą antykwariusza zbiór przynajmniej na początku nie został w żaden sposób specjalnie oznakowany. Jednak w Bibliotece trzymano się zasady, że większe działy wyposażano w osobne, przy sobie stojące szafy i własną numerację prowadzoną dla każdego fundatora. Dlatego na drukach z daru H. Bukowskiego znajdziemy naklejki z oznaczeniem „Buk.” i sygnaturą topograficzną, ,szafa - półka”. Jeszcze przez długi czas używano w Bibliotece określenia „Szafa Bukowskiego"71.

Warto zaznaczyć, że antykwariusz otaczał wyjątkową troską przekazywany AU księgozbiór. Liczący ponad 600 pozycji zbiór stanowił zapewne dla sztokholmskiego bibliofila cenną kolekcję, gdyż jak sam to określił, były „,tam dzieła po większej części drogie lub rzadkie”. Własnoręcznie sporządził

67 BPP, AG, akc. 2697, List H. Bukowskiego do J. Mayera, Sztokholm, 9 XII 1888 r.

68 Tamże.

69 BPP, AG, akc. 2697, List H. Bukowskiego do W. Łuszczkiewicza z dn.13 V 1888 r.

70 Ekslibris Bukowskiego przedstawiający Minerwę w otoczeniu muz został wykonany przez szwedzkiego grafika Roberta Ludwiga Heglunda (1844-1930) około roku 1880, zob. J. Czapla, Inkunabuly szwedzkie w zbiorach biblioteki PAU i PAN w Krakowie, „Rocznik Biblioteki Naukowej PAU i PAN w Krakowie" 2014, t. 59, s. 409.

${ }^{71}$ E.H. Nieciowa, dz. cyt., s. 133. 
i przygotował do druku ich katalog, ,aby [do] zbioru moich książek dostęp był ułatwiony i odnalezienie dzieł łatwiejsze, życzę aby katalog był jak najpraktyczniej urządzony" "72. Wspólnie z W. Łuszczkiewiczem uzgadniał ostateczną wersję jego tytułu, sprawy druku, doboru czcionek. Pisał też, że:

Są tam dzieła z których niewielką będziecie mieli korzyść ale je można ulokować wysoko aby miejsca drogiego tymczasowo nie zabierały. Cała prawie biblioteka jest opatrzona w piękne oprawy a więc gdzie ulokujecie nie będzie bruździła a często może służyć dla introligatorów nawet za wzór ${ }^{73}$.

Przygotowany przez antykwariusza ze Sztokholmu Catalogus librorum... ${ }^{74}$ zawiera 652 pozycje. Pierwszą część obejmuje wielki dział ogólny rejestrujący 539 pozycji. Dalsza część została podzielona na Expositions d'Arts industriels (poz. 540-547), Catalogues de collections privees (poz. 548-562), Ouvrages sur les joyaux et les pierres precieuses taillees (poz. 563569), Taites, Revues et Publications des societes savantes et des Musees (poz. 570-591), Książki nadestane po rozpoczęciu druku katalogu (poz. 592-652).

Po dokładniejszej analizie katalogu można dostrzec w kolekcji antykwariusza bardzo szerokie spektrum tematyczne. Znajdziemy w niej dzieła z dziedziny historii, historii sztuki, archeologii, książki o sztuce, ceramice, numizmatyce, spisy różnych kolekcji (w tym prywatnych), opisy zamków, zbiorów różnych bibliotek, obrazów, portretów. Niewielką część stanowią dzieła literatury pięknej w różnych językach, katalogi wystaw, różnorodnych aukcji. W zbiorze znalazły się też rękopisy czy inkunabuły, ale i m.in. poradniki dotyczące lekcji tańca i nauki czytania run. Pod względem językowym wyraźną przewagę wśród publikacji nad francuskim, niemieckim, rosyjskim, angielskim, łaciną czy bardzo nielicznie występującym polskim ma język szwedzki, co jest oczywiste jeśli się weźmie pod uwagę pochodzenie kolekcji. $\mathrm{Z}$ tej przyczyny J. Mayer zwrócił się do H. Bukowskiego z prośbą o przetłumaczenie tytułów szwedzkich na język polski:

Gdy jednak to [ma] być katalog systematycznie ułożony (czy to ze względu na treść dzieł), między nami zaś nie ma nikogo, kto by władał językiem szwedzkim, przeto zmuszeni jesteśmy przesłać w załączeniu spis dzieł szwedzkich, z prośbą iżby Pan raczył łaskawie każdy tytuł na polski przetłumaczyć i obok szwedzkiego na drugiej połowie zgiętej stronicy go napisaćc ${ }^{75}$.

Antykwariusz spełnił prośbę prezesa AU i przetłumaczył nie tylko tytuły, ale niektóre dzieła zaopatrzył też w obszerniejsze komentarze, opisujące druk

\footnotetext{
72 BPP, AG, akc. 2697, List H. Bukowskiego do W. Łuszczkiewicza z dn. 9 XII 1888 r.

73 Tamże, List H. Bukowskiego do W. Łuszczkiewicza z dn. 20 VIII 1888 r.

74 Catalogus librorum quos ex urbe holmia Academiae Litterarum Cracoviensi dono misit Illm. D H. Bukowski, Kraków 1889; wersja cyfrowa jest dostępna na stronie Biblioteki PAU i PAN w Krakowie, [online] http://149.156.51.45/aktualnosci/183-kolekcja-henryka-bukowskiego-kata$\log$ [dostęp 19.10.2019].

75 BPP, AG, akc. 2699, List J. Mayera do H. Bukowskiego, b.d.
} 
i jego treść, często z adnotacją, że są w niej odniesienia do historii Polski. Jednak analizując całość daru trudno jednoznacznie zaliczyć wszystkie dzieła do poloników. Były wśród nich na przykład takie książki jak Bibliografia szwedzkiej rodziny królewskiej lub też inne podobne, na pierwszy rzut oka nic wspólnego z Polską niemające publikacje. Część z nich można zaliczyć do parapoloników bądź poloników w sensie largo, w tym Bibliografię św. Brigidy (Sztokholm 1883) ${ }^{76}$ autorstwa G.E. Klemminga zawierającą informacje dotyczące Polski. Podobnie jest w Förteckning öfver del uti Riddarholmskyrkan... - wydanym w Sztokholmie w 1875 r. Spisie choragwi ${ }^{77}$, w którym został wydzielony dział Polonica ${ }^{78}$. Jednak trzeba stwierdzić, że polonica sensu stricto są w kolekcji nieliczne.

Ze względu na zawartość kolekcji H. Bukowski proponował, aby trafiła nie do Biblioteki, a do Komisji Sztuki Akademii ${ }^{79}$. Tym sposobem pragnął stworzyć polskim badaczom możliwość zapoznania się z dziełami zagranicznych autorów:

Pragnę i o to proszę P. Prezesa, aby zbiór mój pomieszczony był w ten sposób aby korzystać z niego mogli członkowie Komisji historii sztuki przy poszukiwaniach swych naukowych, jako też badacze nie należące do Komisji mogą za pozwoleniem Dyrektora ze zbioru korzystać ${ }^{80}$.

\section{Muzeum Przemysłowo Techniczne w Krakowie}

Powstało z inicjatywy A. Baranieckiego w 1868 r. Jego misją, według idei założyciela, miał być rozwój oświaty i przemysłu jako jedynej drogi do podniesienia narodu polskiego po klęsce powstania styczniowego ${ }^{81}$. Początkowo placówką zarządzał sam A. Baraniecki, a po jego śmierci w 1891 r. dyrektorem jednej z najważniejszych krakowskich instytucji kulturalnych i edukacyjnych końca XIX w. został były kustosz Muzeum, architekt Jan Wdowiszewski (1853-1904). Wobec braku jakichkolwiek świadectw źródłowych można jedynie przypuszczać, że między A. Baranieckim a H. Bukowskim mogły istnieć kontakty oparte na wspólnych interesach. Znacznie więcej światła na współpracę antykwariusza z władzami Muzeum rzuca, co prawda niezbyt

76 G.E. Klemming, Birgitta-Literatur. Bibliografi, Stockholm 1883.

77 Förteckning öfver del uti Riddarholmskyrkan, förvarade,under framfarna svenska konungars regeringar eröfrade Fanor, Standarer M. FL. Segerbyten samt andra troféer, hvilka befinnas å åtskilliga ställen hörande under Kungl. Landt- och Sjöförsvarsdepart öfverinseende..., upprättad och ordnad af F.W. Ekstrom, Stockholm 1875.

78 Tamże, s. 5.

79 Zob. BPP, AG, akc. 2697, List H. Bukowskiego do W. Łuszczkiewicza z 20 VIII 1888 r.

80 Zob. tamże, List H. Bukowskiego do J. Mayera z dn. 9 XII 1888 r.

81 P. Hapanowicz, Działalność Muzeum Techniczno-Przemysłowego w Krakowie i jego likwidacja w latach 1949-1950, „Zarządzanie w Kulturze” 2007, t. 8, s. 44. 
liczna, jednak zachowana w BPP w Archiwum Gierszyńskich jego korespondencja z J. Wdowiszewskim.

Z listów dyrektora do H. Bukowskiego dowiadujemy się, że w 1892 r. antykwariusz przekazał do Muzeum dar, który między innymi przedmiotami zawierał:

Osiemnaście roczników publikacji dotyczących szwedzkiego i obcokrajowego artystycznego przemysłu, wykonanej w litografiach lub fototypiach pod tytułem Mönster för konstindustri och slöjd utgifna af svenska slöjdföreningen od roku $1873-1891^{82}$.

W następnych latach ich korespondencja jest znacznie częstsza i wyraźnie bardziej wylewna. Dyrektor nie ogranicza się do konwencjonalnego podziękowania za przekazane dary, wysyłając obszerne listy z ciepłymi i pełnymi uznania słowami dla ofiarodawcy:

List, jakim byłeś łaskaw zaszczycić mnie, Czcigodny Panie, dając znać o otrzymaniu podziękowania za swoje piękne dary dla Muzeum, zawiera tak szczere i drogie słowa, że w duszy Polaka odzywa się cała satysfakcja i radość, iż dawna gotowość nasza w poświęceniu dla sprawy publicznej nie tylko nie wygasła, ale owszem zmaga się i rośnie, im bardziej los i nieszczęśliwa przeszłość Ojczyzny, - oddalenie od niej i zawiązanie żywych stosunków na obczyźnie zdawałyby się usprawiedliwiać i uprawnić stygnięcie uczuć. Ale jest to właśnie ta sławna moc i tęgość prawdziwej, głębokiej Polskości, że im boleśniej się cierpi dla godnego przedmiotu, tym się go goręcej kocha ${ }^{83}$.

Z listu dowiadujemy się równocześnie, że H. Bukowski przekazał wówczas Bibliotece Muzeum:

śliczną artystycznie i pełną wartości podobiznę średniowiecznej książki do nabożeństwa Livre d'heures, dar prawdziwie wspaniały i tym donioślejszy, że się podobno wiąże z osobistą pamięcią króla Karola XV-go [...], dalsze części katalogu zbiorów Hammera ${ }^{84}$.

Niestety, nie udało się zidentyfikować ani miejsca, ani daty wydania wspomnianej książki, jak również katalogów. Być może wymienione pozycje mogły zaginąć w czasie przeprowadzki Muzeum do nowego gmachu przy ul. Smoleńsk wybudowanego w latach 1910-1914, bądź przy okazji likwidacji Muzeum w 1950 r. i przejęcia zbiorów jego Biblioteki przez Bibliotekę Akademii Sztuk Pięknych w Krakowie ${ }^{85}$.

Także w 1892 r. ze Szwecji do Biblioteki Muzeum trafił zbiór katalogów aukcyjnych $\mathrm{H}$. Bukowskiego, który przez dyrektora Muzeum został uznany

82 BPP, AG, akc. 2699, Podziękowanie Zarządu Muzeum Techniczno-Przemysłowego dla H. Bukowskiego za złożone dary, 3 IX $1892 \mathrm{r}$.

83 Tamże, List J. Wodziszewskiego do H. Bukowskiego z dn. 12 XI 1895 r.

84 Tamże.

85 J. Wielgut-Walczak, Biblioteka Muzeum Techniczno-Przemysłowego w Krakowie (18681950). Zarys dziejów, „Annales Academiae Pedagogicae Cracoviensis”, f. 39, „Studia ad Bibliothecarum Scientiam Pertinentia IV" 2006, s. 73-74. 


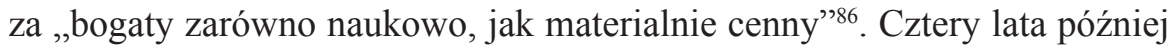
antykwariusz przekazał nieopisane w źródłach stare druki, oraz dzieło Pompa funebris ... Alberti Pii..., wydane w Brukseli w roku 1623, opatrzone miedziorytami flamandzkiego artysty Jacoba Franquarta (1582/83-1651), które, jak ujął dyrektor Muzeum: ,nie tylko same przez się, ale zwłaszcza dla biblioteki naszej mają niepospolitą wartość" ${ }^{87}$. Również w kolejnych latach antykwariusz nie zapominał o wspieraniu darami książkowymi Biblioteki Muzeum Przemysłowo-Technicznego w Krakowie. Jednak wiadomo o tym wyłącznie z następnych listów dyrektora placówki do H. Bukowskiego. Z przykrością trzeba stwierdzić, że w korespondencji tej dary nie zostały wymienione; nie pozostał też po nich żaden ślad w muzealnych sprawozdaniach i księgach akcesyjnych.

\section{Podsumowanie}

Zaangażowanie $\mathrm{H}$. Bukowskiego w wyszukiwanie i nabywanie wszystkiego, co można określić mianem polonicum sensu stricto lub largo ${ }^{88}$ było godne podziwu. Motywacją do takich działań była bezgraniczna miłość Polaka do utraconej Ojczyzny oraz niepohamowane pragnienie wsparcia jej wszelkimi możliwymi sposobami. Antykwariusz realizował swój cel życiowy tak, jak mógł najlepiej. Wykorzystując swoją ogromną wiedzę - wielu bywalców antykwariatu H. Bukowskiego nazywało go ,polską stacją naukową” w Sztokholmie - wyszukiwał rozproszone po całej Europie polonica, gromadził je najpierw w swoim zakładzie, a potem rozdzielał sprawiedliwie i z wielkim znawstwem po instytucjach w Polsce i na emigracji.

Czy to ze względów personalnych ${ }^{89}$, czy z innych przyczyn, szczególnym wsparciem sztokholmskiego antykwariusza cieszyły się biblioteki krakowskie. Każda z nich była obdarowywana według jego uznania tym, co jego zdaniem najbardziej pasowało do jej zbiorów.

86 BPP, AG, akc. 2699, List J. Wdowiszewskiego do H. Bukowskiego z dn. 3 X 1895 r.

87 Tamże, List J. Wdowiszewskiego do H. Bukowskiego z dn. 20 V 1896 r.

88 Może warto przypomnieć, że w rozumieniu szwedzkiego antykwariusza było to pojęcie wyjątkowo szerokie. Obejmowało wszelkie przedmioty, wyroby artystyczne, wykopaliska, inkunabuły, starodruki, druki nowsze, nie tylko pochodzące z ziem polskich w najszerszym znaczeniu, ale również pod względem zawartości mające jakikolwiek wiązek z historią Polski.

89 Mężem Marii Bukowskiej (córki Bukowskiego) był doktor W. Harajewicz pochodzący ze znanej krakowskiej rodziny lekarzy. Zięć nie tylko niejednokrotnie pośredniczył w przekazywaniu darów antykwariusza do Muzeum w Rapperswilu oraz do Krakowa, ale też sam był zagorzałym kolekcjonerem i darczyńcą. Natomiast jego ojciec był członkiem korespondentem Muzeum Narodowego w Rapperswilu. Zob. S. Żeromski, Listy do Henryka..., s. 373; Z. Miłkowski, Listy do Henryka Bukowskiego z lat 1889-1900, wstęp i oprac. D. Ossowska, Olsztyn 2001, s. 22; ,Sprawozdanie z Zarządu Muzeum Narodowego w Rapperswylu za Rok [1892]” 1893, R. 22, s. 9. 


\section{Bibliografia}

Archiwalia i rękopisy:

Archiwum Muzeum Narodowego w Krakowie, sygn. 94-10, Inwentarz Władysława Łuszczkiewicza z r. 1885.

Biblioteka Jagiellońska, Księgi akcesyjne Biblioteki Jagiellońskiej, 1891, 1884-1899, rps. Biblioteka Polska w Paryżu, Archiwum Gierszyńskich.

Publikacje:

Baran W., Henryk Bukowski. Wielki bibliofil polski, Warszawa-Kraków 1926.

Bender R., Ignacy Polkowski (1833-1888), [w:] Polski słownik biograficzny. T. 27: Pniowski Jan - Potocki Ignacy, Wrocław 1983, s. 322-324.

Beniowski M.A., Lefnadslopp och Resor, af honom sielf beskrefne, Stockholm 1791.

Benzelstierna Engeström W., Henryk Bukowski (wspomnienie pośmiertne), Poznań 1900. Berbelicki W., Dary dla Biblioteki Jagiellońskiej w latach 1868-1904, Kraków 1959.

Bojarska I., Adrian Baraniecki (1828-1891), [w:] Polski słownik biograficzny. T. 1: Abakanowicz Abdank Bruno - Beynart Wojciech, Kraków 1935, s. 270-271.

Brzeski J.W., Środowisko Biblioteki Jagiellońskiej w latach 1775-1939. Stownik biograficzny, Kraków 2014.

[Bukowski H.], Katalog rzadkich druków polskich ze zbiorów H. B. w Sztokholmie. Oddruk z katalogu ogólnego od Nr 1501 do 1895, w 22 egzemplarzach, Stockholm 1887.

Catalogus librorum quos ex urbe holmia Academiae Litterarum Cracoviensi dono misit Illm. D.H. Bukowski, Kraków 1889, [online] http://149.156.51.45/aktualnosci/ 183-kolekcja-henryka-bukowskiego-katalog [dostęp 19.10.2018].

Ciesielski Z., Przypomnienie Henryka Bukowskiego, [w:] Zbliżenia skandynawsko-polskie. Szkice o kontaktach kulturalnych w XIX i XX wieku, Gdańsk 1972, s. 236-240.

Czapla J., Inkunabuły szwedzkie w zbiorach biblioteki PAU i PAN w Krakowie, „Rocznik Biblioteki Naukowej PAU i PAN w Krakowie” 2014, t. 59, s. 407-412.

Estreicher K., Bibliografia polska. Cz. 3, t. 20, Kraków 1936.

Estreicher K., Kronika Biblioteki Uniwersytetu Jagiellońskiego od 1811 roku, opr. i wstęp J. Brzeski, Kraków 2012.

Estreicher K., O Rapperswylu. Głos drugi i ostatni, Kraków 1883.

Folejewski Z., Henryk Bukowski, „Svio-Polonica” 1944-1945, nr 6-7, s. 62-65.

Förteckning öfver del uti Riddarholmskyrkan, förvarade,under framfarna svenska konungars regeringar eröfrade Fanor, Standarer $m$. $f$. Segerbyten samt andra troféer, hvilka befinnas å åtskilliga ställen hörande under Kungl. Landt- och Sjöförsvarsdepart öfverinseende departementens öfverinseende, m.m. På Hns Majt Konungens Nådiga befallning, upprättad och ordnad af F.W. Ekstrom, Stockholm 1875.

Gierszyński H., H. Bukowski. Wspomnienie pośmiertne z portretem, Paryż 1900. 
Hapanowicz P., Działalność Muzeum Techniczno-Przemysłowego w Krakowie i jego likwidacja w latach 1949-1950, „Zarządzanie w Kulturze” 2007, t. 8, s. 42-62.

Haykowski M., Henryk Bukowski. Namnet lever kvar, Stockholm 1990.

Hulewicz J., Związki Estreichera z Akademia Umiejętności, [w:] Księga pamiątkowa ku czci Karola Estreichera (1827-1908). Studia i rozprawy, Kraków 1964, s. 281-327.

Katalog poloników XVI wieku Biblioteki Jagiellońskiej. T. 1-3, pod red. M. Malickiego i E. Zwinogrodzkiej, Kraków 1992-1995.

Klemming G.E., Birgitta-Literatur. Bibliografi, Stockholm 1883.

Korzon T., Nekrologia. Henryk Bukowski, „Kwartalnik Historyczny” 1900, R. 14, s. 367-374.

Lewak A., Bukowski Henryk (1839-1900), [w:] Polski słownik biograficzny. T. 3: Brożek Jan - Chwalczewski Franciszek, Kraków 1937, s. 120-121.

Miłkowski A., Listy do Henryka Bukowskiego z lat 1889-1900, wstęp i oprac. D. Ossowska, Olsztyn 2001.

Mroziewicz K., "Regum Poloniae Icones» Tomasza Tretera ze zbiorów Biblioteki Królewskiej w Sztokholmie i szwedzkie watki w listach serii, „Folia Historiae Artium. Seria Nowa" 2017, t. 15, s. 25-34.

„Muzeum Narodowe. Sprawozdanie Zarządu za Rok 1889” 1890.

Nieciowa E.H., Stanisław Windakiewicz jako bibliotekarz, „Rocznik Biblioteki Polskiej Akademii Nauk w Krakowie" 1968, R.14, s. 125-142.

Nordisk familijebok, [online] http://runeberg.org/nfbj/0678.html [dostęp 19.10.2018].

Polski stownik biograficzny. T. 7: Firlej Jan-Girdwoyń Kazimierz, Warszawa 1948-1958.

Przybyszewski S., Moi współcześni, Warszawa 1959.

Słownik pracowników książi polskiej, pod. red. I. Treichel, Warszawa-Łódź 1972.

„Sprawozdanie z Zarządu Muzeum Narodowego w Rapperswylu za Rok [1892]” 1893, R. 22.

„Sprawozdanie z Zarządu Muzeum Narodowego w Rapperswylu za Rok [1900]” 1901, R. 31.

Stankiewicz W., Listy Henryka Bukowskiego do rodziny Gierszyńskich. Źródło do dziejów Muzeum Polskiego w Rapperswilu. [Cz. 1], Warszawa 1971.

Szyndler B., Bibliotekarska służba Stefana Żeromskiego, Wrocław 1977.

Śladkowski W., Wysepka polska we Francji. U Marii i Henryka Gierszyńskich w Ouarville. 1878-1930, Lublin 2005.

Świderska A., Henryk Bukowski, [w:] Słownik pracowników książki polskiej, pod. red. I. Treichel, Warszawa-Łódź 1972, s. 99-100.

Wielgut-Walczak J., Biblioteka Muzeum Techniczno-Przemysłowego w Krakowie (18681950). Zarys dziejów, „Annales Academiae Pedagogicae Cracoviensis”, f. 39, „Studia ad Bibliothecarum Scientiam Pertinentia IV" 2006, s. 67-76.

Więckowska H., Ksawery Bronikowski (1783-1834), [w:] Polski słownik biograficzny. T. 2: Beyzym Jan - Brownsford Maria, Kraków 1936, s. 468-470 .

Zajewski W, Roman Soltyk (1790-1843), [w:] Polski słownik biograficzny. T. 40: Soczyński Karol - Sowiński Ignacy, Warszawa-Kraków 2000-2001, s. 420-424. 
Ziembicki W., Władysław Bylicki (1846-1931), [w:]. Polski słownik biograficzny. T. 3: Brożek Jan - Chwalczewski Franciszek, Kraków 1937, s. 170.

Żeromski S., Henryk Bukowski, „Tygodnik Ilustrowany” 1900, nr 12, s. 226-227.

Żeromski S., Listy do Henryka Bukowskiego, oprac. wstęp, koment. W. Wasilewska, Warszawa 1975.

Żeromski S, Ludzie bezdomni, T. 1-2, Warszawa 1958. 